\title{
Can Diagenetic Processes Influence the Short Term Hydraulic Behaviour Evolution of a Fault?
}

\author{
C. Frima ${ }^{1}$, I. Moretti ${ }^{1}$, E. Brosse ${ }^{1}$, F. Quattrocchi ${ }^{2}$ and L. Pizzino² \\ 1 Institut français du pétrole, 1 et 4, avenue de Bois-Préau, 92852 Rueil-Malmaison Cedex - France \\ 2 Istituto Nationale di Geofisica e Vulcanologia (INGV), Via di Vigna Murata 605, 00 143, Roma - Italia \\ e-mail: cfrima@netcourrier.com - isabelle.moretti@ifp.fr - etienne.brosse@ifp.fr - quattrocchi@ingv.it - pizzino@ingv.it
}

\begin{abstract}
Résumé - Les processus diagénétiques peuvent-ils influencer à court terme le comportement hydraulique dans une faille ? - L'objectif de cette étude est de quantifier l'impact du colmatage de fractures par de la calcite sur le comportement hydraulique d'une faille active dans les carbonates. Le contexte est celui de la faille sismique d'Aigion, dans le golfe de Corinthe, en Grèce, étudiée dans le cadre du Corinth Rift Laboratory (CRL). Ce travail repose sur l'examen de carottes et d'échantillons de fluides recueillis de part et d'autre de la faille lors d'une campagne de forage. Les données incluent les informations pétrostructurales des carottes, la géochimie des fluides du toit de la faille, ainsi que l'imagerie de puits et les tests de pompage. Les échantillons montrent un grand nombre de fractures récentes partiellement ou complètement colmatées par des cristaux de calcite. Nous avons modélisé les interactions eau/roche pour quantifier le taux de croissance de la calcite dans ces fractures. Cette modélisation fut menée avec Diaphore, un logiciel spécialement conçu pour étudier l'évolution diagénétique de la porosité dans les réservoirs pétroliers. Les résultats montrent que le temps requis pour colmater une fracture de $1 \mathrm{~mm}$ d'épaisseur, dans le cas de la faille d'Aigion, à $760 \mathrm{~m}$ de profondeur, est de l'ordre de la centaine d'années, avec la composition de l'eau échantillonnée dans la zone de fracture. En conséquence, les processus diagénétiques peuvent avoir une influence sur le comportement hydraulique à l'échelle du cycle sismique. Cependant, le comportement de la calcite dépend largement de la composition du fluide. Des tests réalisés avec une eau marine et une valeur légèrement plus élevée de $p \mathrm{CO}_{2}$, c'est-à-dire dans des conditions vraisemblables à proximité de la faille, montrent qu'au contraire, il peut y avoir dissolution de la calcite.
\end{abstract}

\footnotetext{
Abstract - Can Diagenetic Processes Influence the Short Term Hydraulic Behaviour Evolution of a Fault? - The scope of this work is to quantify the impact of calcite cementation on the hydraulic behaviour of an active fault in carbonate rocks. In the studied context, the permeability mainly depends on the fracture network. Therefore the hydraulic regime depends on the way fractures become sealed by vein deposits. The work is based on the study of cores and groundwater recovered from an active normal fault in the Gulf of Corinth, the Aigion fault, in the framework of the Corinth Rift Laboratory Project. The data set includes cores, borehole images, pumping tests and in situ fluid samples. The cores show numerous recent fractures partially, or completely, sealed by recent carbonate crystals. We modelled the fluid-rock interaction to quantify the growth rate of calcite in the veins of this specific geological context. Modelling was carried out with Diaphore, a software designed to study the diagenetic evolution of porosity in hydrocarbon reservoirs. The required time to seal a $1 \mathrm{~mm}$ thick fracture in the case of the Aigion
} 
fault at $760 \mathrm{~m}$ depth was calculated to be within the range of a few hundred years, considering the composition of water sampled at this depth. As a conclusion, diagenetic processes are likely to have a key influence on the fault hydraulic behaviour over the time scale of seismic cycles. However, the possibility of calcite growth strongly depends on the composition of the fluid. Tests were made with seawater and slightly higher values of $\mathrm{pCO}_{2}$, a fluid that could also be present around the Aigion fault. In this case dissolution, and therefore opening of the fractures, happens.

\section{INTRODUCTION}

Fault and fracture hydraulic behaviour is a key problem for many geoscientists. A huge amount of literature has been focused on this issue. Nevertheless, the prediction of such behaviour remains uncertain since many parameters have an influence on it. The surrounding rocks, the pressure gradients, the stress field, the fractures orientation are some of these parameters. As several of them evolve with time, changes of fault hydraulic behaviour are likely to occur during geological history. These changes may be due to the stress-field evolution and to the fluid-rock interactions. In the frame of the ongoing active research on the fluid-strain relationship, the present paper focuses on the link between hydraulic conductivity and water-rock interaction in a fault zone, in the carbonate context of the Gulf of Corinth.

Because of kinetic rates the diagenetic processes can be fast in a carbonate context, compared to other geological phenomena. Case studies have shown that reservoir porosities in hydrocarbon fields may change during the production period, due to water-rock interaction (e.g., Hutcheon and Abercrombie, 1990). In compact carbonates, faults and fractures provide the main conduits for fluids and the place for mineral reactions. Understanding how they control fluid flow in this setting is a major issue for water resources and hydrocarbon production. Moreover, fluid circulation in the upper crustal level is known to be also related to strain and earthquakes (Sibson, 1994, among others). Many authors have emphasised the flow variations due to seismic events (e.g., Muir Wood and King, 1993). In another approach, models that link the fluid pressure to the friction coefficient along the fault plane and therefore to seismicity have been proposed (Evans, 1992; Sibson, 1992). The monitoring of active faults in order to acquire the data that will allow the earth science community to solve this important problem started in Japan, on the Kobe fault; in the United States, on the San Andreas fault; and in Europe, on the Corinth Rift (Moretti et al., 2002). All these projects lead to the drilling, coring and monitoring of faults and our study is based on the data coming from the AIG-10 well drilled through an active normal fault (the Aigion fault) in the southern shore of the Gulf of Corinth, $50 \mathrm{~km}$ eastward Patras (Fig.1) thanks to the cluster of European research projects called the "Corinth Rift Laboratory" CRL (Cornet et al., 2004).

From the petrologic description of cements in different fractures and interstitial waters sampled at AIG-10 well, this paper aims to test the influence of several parameters on the growth rate of calcite. We want thus to compare the timing of calcite formation in veins with the seismic cycle. The precipitation of calcite in a fractured zone was calculated by the reaction-transport code Diaphore that takes into account the transfer of dissolved elements by water movement, the kinetic rates of the mineral reactions and the feedback of reactions on petrophysical properties. It simulates calcite growth in a fracture by interaction between fluid and rock. Many authors worked on the kinetics of calcite growth particularly in the context of fracture filling (Mucci and Morse, 1983; Mucci, 1986; Zhong and Mucci, 1989; Dromgoole and Walter, 1990; Shiraki and Brantley, 1995; Lebrón and Suarez, 1998; Nilsson and Sternbeck, 1999). In a series of numerical simulations we here use:

- the experimental results published by Lee et al. (1996) and Lee and Morse (1999) to calibrate the rate of calcite growth;

- rock characteristics and fluid composition acquired from samples of AIG-10 well.

A key parameter to quantify the fracture sealing is the precipitation rate of calcite, which depends on flow rate, pressure variation, fracture thickness and fluid composition (Lee $e t$ al., 1996; Lee and Morse, 1999). The calibrated model was able to calculate the thickness of the calcite deposit on the vein wall versus time and allowed the time required for the occlusion of a fracture by diagenetic cementation to be estimated.

\section{GEOLOGICAL SETTING OF THE AIGION FAULT}

\subsection{Regional Context and Seismicity}

The $C R L$ is located on the southern coast of the Gulf of Corinth (Moretti et al., 2002). In this area, the inherited Hellenides structures are mainly west verging along NS to NW-SE thrusts and they are affected by Miocene and Pliocene extension (Ori, 1989; Armijo et al., 1996; Moretti et al., 2003; and many others). The Aigion fault is one of the very recent faults that border the southern shore of the Gulf of Corinth and developed during its current tectonic phase that started about 1 My ago (Sorel, 2000; Westaway, 2002; Moretti et al., 2003). The Aigion fault is an E-W oriented structure (Fig. la) deeping at $60^{\circ} \mathrm{N}$ (Micarelli et al., 2003). The offset of the fault is about $180 \mathrm{~m}$ (Naville et al., 2004) and its age is less than $50000 \mathrm{y}$ based on the measured slip 

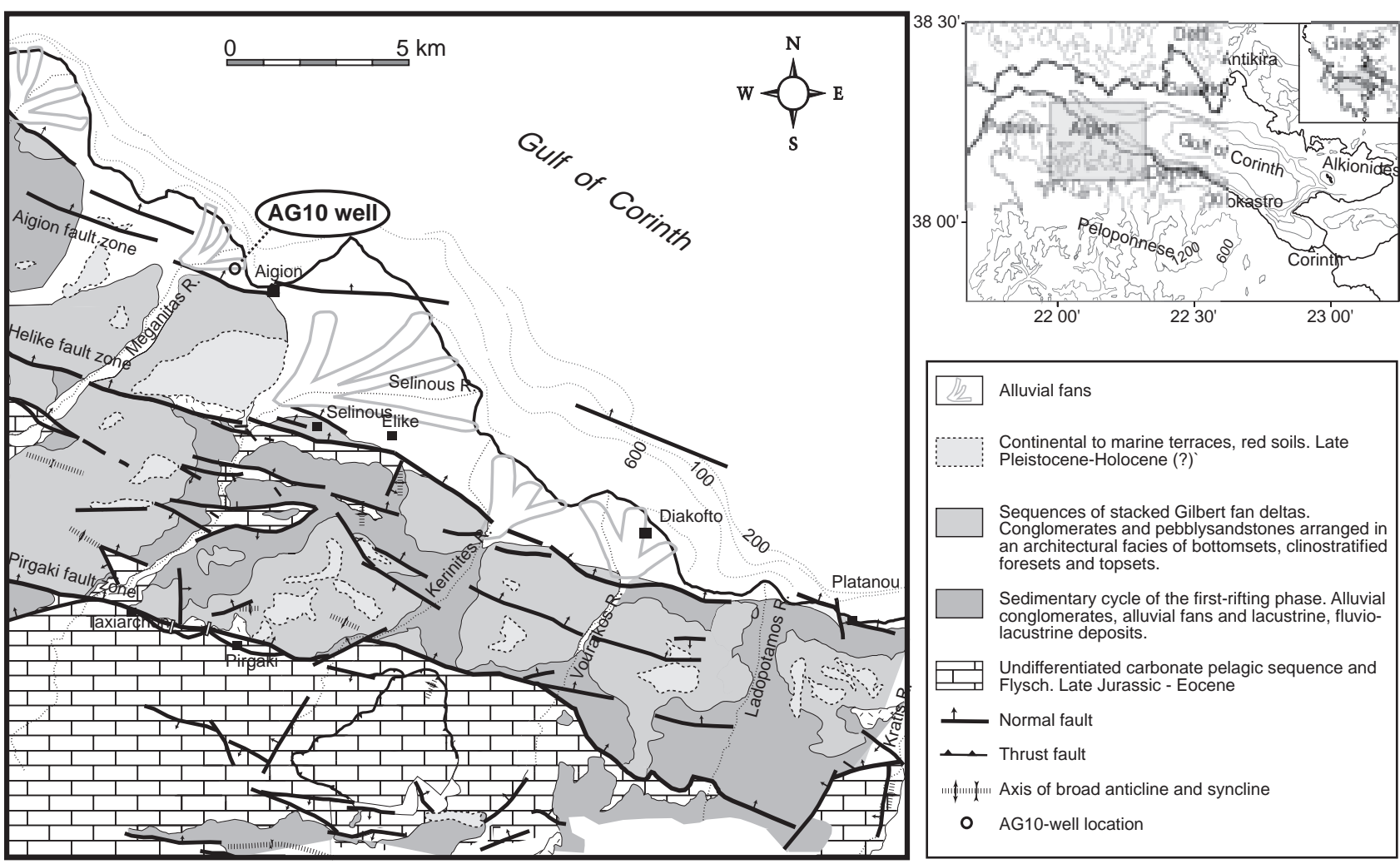

2 Alluvial fans

Continental to marine terraces, red soils. Late Pleistocene-Holocene (?)

Sequences of stacked Gilbert fan deltas

Conglomerates and pebblysandstones arranged in an architectural facies of bottomsets, clinostratified foresets and topsets.

Sedimentary cycle of the first-rifting phase. Alluvial conglomerates, alluvial fans and lacustrine, fluviolacustrine deposits.

Undifferentiated carbonate pelagic sequence and Flysch. Late Jurassic - Eocene

$\perp$ Normal fault

L_. Thrust fault

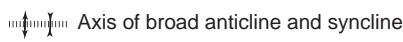

- AG10-well location

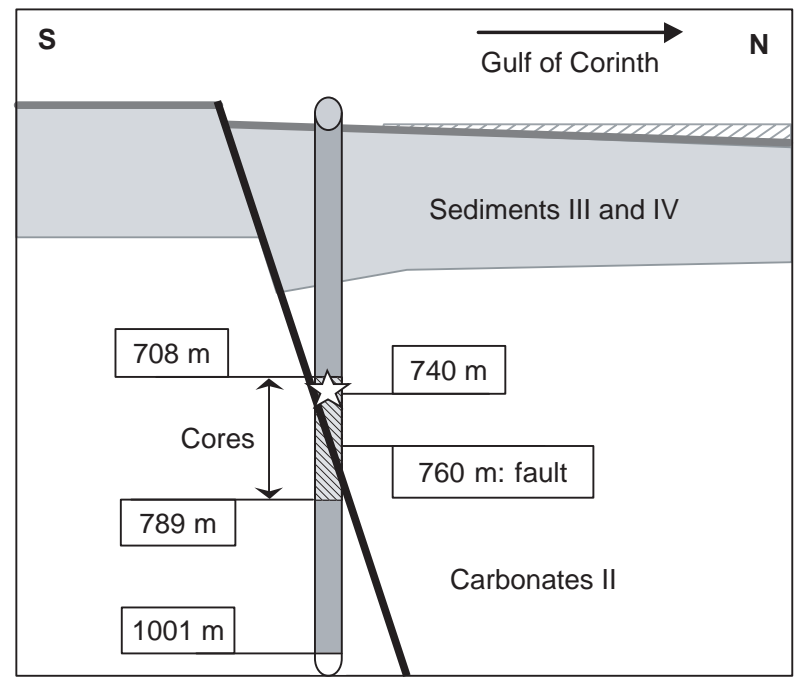

$\hat{\imath}$ Localisation of the pumping test where the fluid sample was collected.

Water sample: - in carbonates II;

- at a depth of $740 \mathrm{~m}$;

- at $10 \mathrm{~m}$ cloth to the Aigion fault.

b)

Figure 1

The Aigion Fault in the Peloponnese.

a) map of the studied area (modified from Micarelli et al., 2003).

b) situation of the cores crossing the Aigion fault in the well AIG-10 and of the pumping test. 
rate. Recent seismicity in the area and along this particular fault is known from historical records as well as from geological data. A large earthquake affected the Aigion City area in June 1995 (Koukouvelas and Doutsos, 1996). Surface ruptures have been observed on the scarp of the Aigion fault. Nevertheless, the 1995 epicentre was located northward offshore, and the subsurface rupture plane is more likely linked to another fault, also deeping northward and located offshore (Bernard et al., 1997). The link between the outcropping high angle normal faults and the rupture plane determined by the seismologists is open to discussion. The seismogenic zone starts at $5 \mathrm{~km}$ depth below the Aigion/Helike area and deepens northward (Rigo et al., 1996). Earthquakes located beneath the northern shore usually indicate extensional failure on E-W planes dipping $20^{\circ}-40^{\circ}$ North (Rietbrock et al., 1996; Bernard et al., 1997). Fault planes exposed at surface in the Aigion area are considerably steeper, and the fault dips in the range $55^{\circ}-70^{\circ}$, as observed (Micarelli et al., 2003). Many authors consider now that this seismogenic zone corresponds to an inherited weak zone, the Phylliades nappes (Le Pourhiet et al., 2004) and that the branching of the high angle outcropping normal fault and this decollement level is sharp, the outcropping faults keeping their high angle over few kilometers.

The paleoseismicity of the area is known from archaeological records and trenches across the Helike and Aigion faults (Fig. 1b). In both cases the inter-seismic event period is a few centuries long: Pantosti et al. (2002) proposed a maximum inter-event interval for the Aigion fault c.a. $360 \mathrm{y}$, whereas on the Helike fault, Koukouvelas et al. (2001) documented three majors events during the last 2000 y (with offset over an half meter) that lead to a longer inter-seismic period. The last large event, on the Helike fault, occurred in 1861 .

\subsection{The AIG-10 Well}

The well AIG-10, drilled vertically, intersected the Aigion fault at $761 \mathrm{~m}$ depth (Fig. $1 \mathrm{~b}$ and 2). It was cored between 710 and $791 \mathrm{~m}$ (Moretti et al., 2002) and borehole images (UBI and FMI) were acquired from 710 down to $1003 \mathrm{~m}$ depth. In this section, turbiditic deep marine carbonates were found, characterized by mudstone to grainstone limestones intercalated with marls and thin shaly layers (Daniel et al., 2004). A detailed description of the well can be found in Rettenmaier et al. (2004). The rocks are mainly composed of carbonates but the fault core consists of radiolarite material predominantly made of silica and red marls. The gouge (lato sensu) is $2.5 \mathrm{~m}$ thick and the damaged zone formed by cataclastic bands and highly fractured material is $25 \mathrm{~m}$ thick in the hanging wall (Micarelli et al., 2003; Daniel et al., 2004). Deformations in the hanging- and footwall are not similar: carbonates in the footwall show fractures and dissolution whereas in the hanging wall, carbonates are fractured and show a gradation of sealing with calcite and/or marls. Cores from the hanging wall show an evolution of the deformation patterns and fracture density that depend on the distance to the fault (Micarelli et al., 2003). These fractures are either empty, sealed or partially sealed with automorphous calcite crystal and/or breccias (Fig. 2). Void percentage increases close to the fault. Nevertheless, the fault itself is impermeable as confirmed by the gap of pressure encountered on both sides (Cornet et al., 2004).

Neoformed calcite veins and crystals observed above the fault are spectacular (Fig. 2). Calcite minerals are automorphous, plurimillimeter and translucide. In contrast, thick calcite deposits are missing in the footwall. A thin film of calcite borders the carbonates clast under the fault but huge voids are present, suggesting dissolution. The high water pressure below the fault, and the borehole images, confirmed that the footwall was affected by karstification. Fluid was sampled from the fault zone and below, and analysed as detailed in Section 2.3.

As a conclusion, the dominant diagenetic processes were different on both sides of the Aigion fault. They resulted in precipitation of calcite in the hanging wall and dissolution of calcite in the footwall. It is beyond the scope of the present contribution to understand how the differences between the rocks and the fluids, above and below the fault, explain the existence of two separate mineral-assemblage/fracture systems. We focus here on the analysis of the calcite-veins growth in the hanging wall. Our aim is to quantify the rate of the fracture occlusion by calcite above the fault. The hypothesis that considers the relation between calcite growing rate, the permeability changes versus time and seismicity will be discussed.

\section{DIAPHORE: REACTION - TRANSPORT MODEL}

\subsection{Fundamentals of the Model}

Diaphore (DIAgenetic Processes in Heterogeneous Oil REservoirs) is a geochemical "reaction-transport" software designed to simulate diagenetic reactions (Brosse et al., 2003). Equilibrium between dissolved species is assumed. Activity corrections are computed according to the extended Debye-Hückel formulation (or B-dot) for ionic species and other formalisms for neutral species, dissolved gases and $\mathrm{H}_{2} \mathrm{O}$ (detailed in Fritz, 1981).

Diaphore is applicable to a rock system made of grains and saturated by water. The code simulates the dissolution and the precipitation of minerals which are out of equilibrium (Fig. 3a), according to kinetic rates of the general form:

- for mineral dissolution: $R_{d}=-k_{d} \cdot A \cdot\left(1-\frac{Q}{K_{e q}}\right)$ 


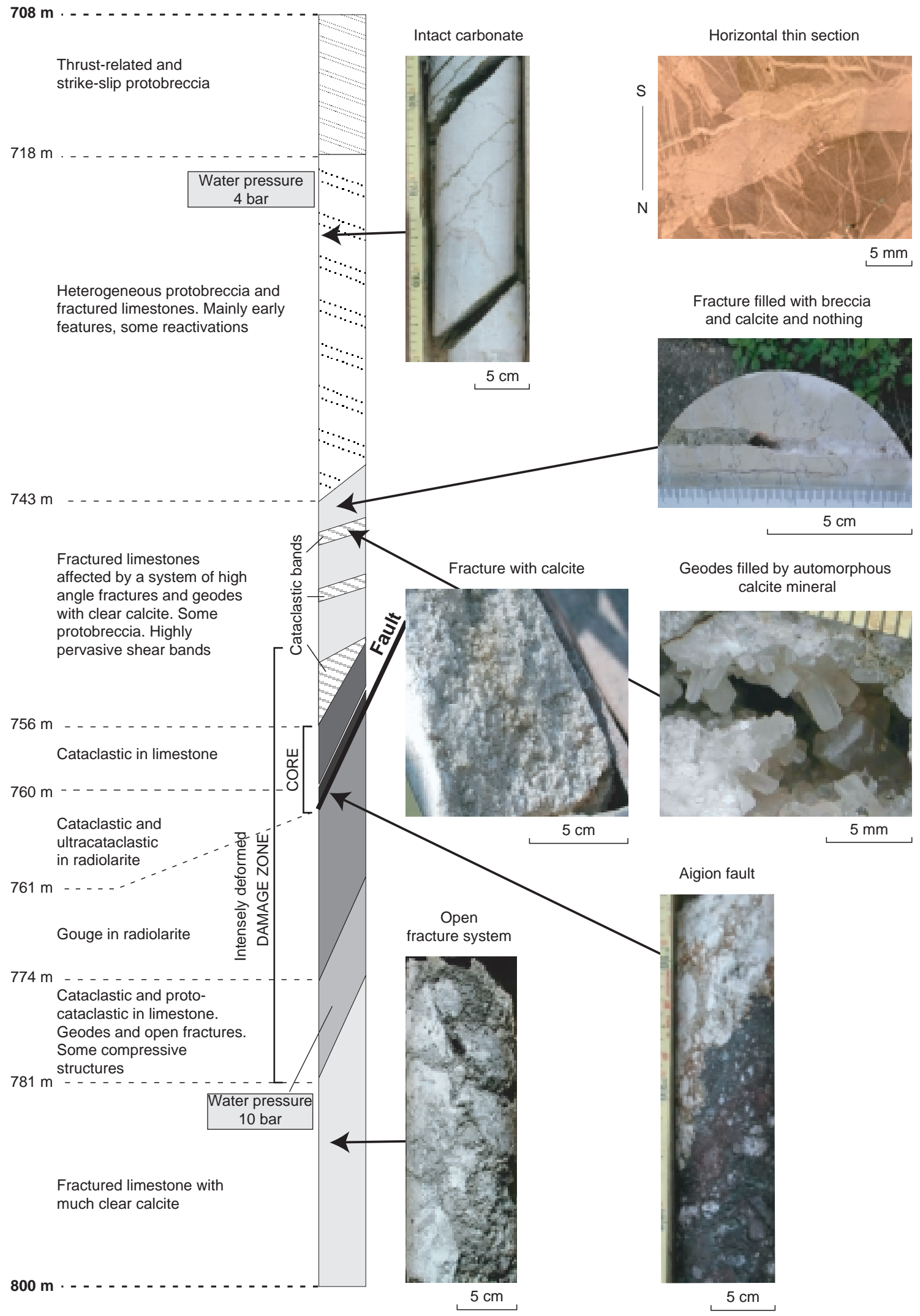

Figure 2

Schematic description of the Aigion well (AIG-10). 

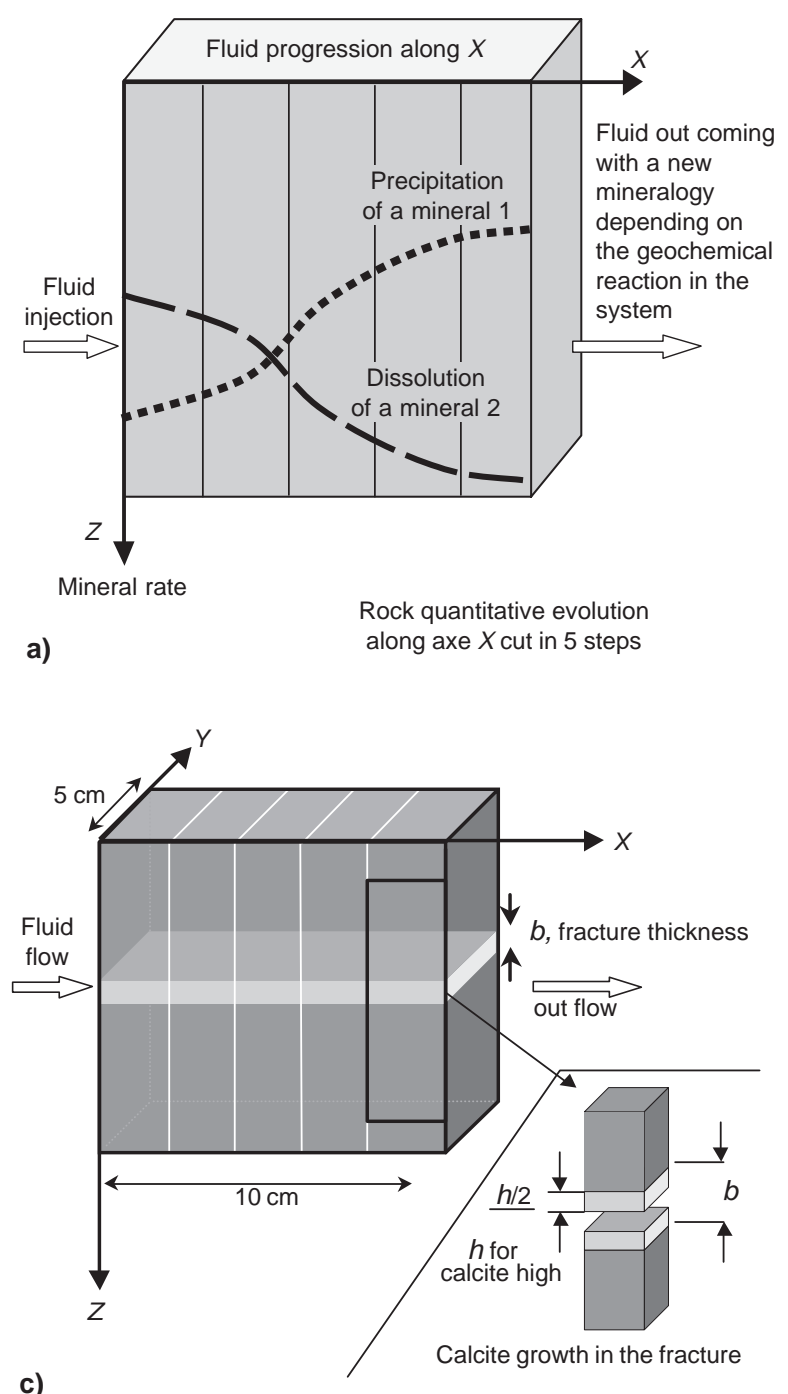

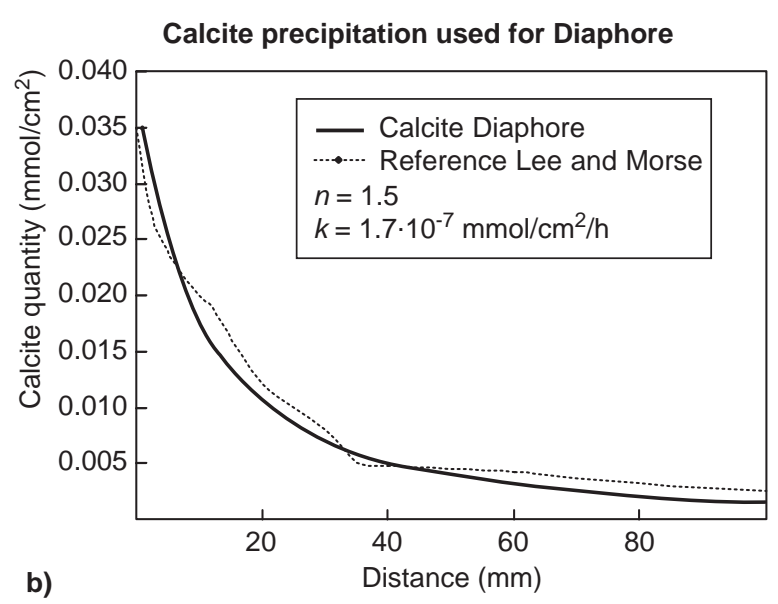

Figure 3

Diaphore: principle, calibration and geometry.

a) diaphore principle: a system crossed by a fluid flow along $X$-axis. Precipitation and dissolution phenomena along the system at a given time.

b) calibration of calcite growth kinetics along the fracture, based on the Lee and Morse's (1999) experiment.

c) the geometry of the system in which calcite precipitates along the $X$-axis is cut in five steps. One of these steps is represented on the right side showing the length, $h$, of calcite precipitation in the fracture of initial thickness $b$. In the following figures the horizontal axis of the fracture is represented as the $X$-axis, numbered by the cell number from 1 to 5 , each cell being $2 \mathrm{~cm}$ long. The inlet the first cell and outlet the last one, in the direction of flow.
- for mineral growth: $R_{p}=-k_{p} \cdot A \cdot\left[\left(\frac{Q}{K_{e q}}\right)^{\alpha}-1\right]^{\beta}$

where:

- $R_{d}$ and $R_{p}\left(\mathrm{~mol} \cdot \mathrm{l}^{-1}\right.$ solution $\left.\cdot \mathrm{y}^{-1}\right)$ stand respectively for the dissolution and precipitation rate of the mineral;

- $k_{d}\left(\mathrm{~mol} \cdot \mathrm{m}^{-2}\right.$ mineral $\left.{ }^{-1}\right)$ is the dissolution rate constant, that depends on temperature and $\mathrm{pH}$;

- $k_{p}\left(\mathrm{~mol} \cdot \mathrm{m}^{-2}{ }_{\text {mineral }} \cdot \mathrm{y}^{-1}\right)$ is the growth rate constant;

- $A\left(\mathrm{~m}_{\text {mineral }}{ }^{1}{ }^{-1}\right.$ solution $)$ represents the reactive surface area per unit volume of solution;

- $K_{e q}$ is the thermodynamic constant of the mineral hydrolysis;

- $Q$ is the corresponding activity product;

$-\alpha$ and $\beta$ are two coefficients.

Usually, the parameters $k_{d}, k_{p}, \alpha$ and $\beta$ of the formalism are calibrated from laboratory experiments. Dissolution or precipitation induces changes of porosity and surface area. A new permeability value is deduced, from routine formalisms (e.g., the Kozeny Equation).

The percolation of the water through the system by which reactions appear can be performed either at a constant fluid flow $\left(\mathrm{m}^{3} \cdot \mathrm{d}^{-1}\right)$ or at constant pressure gradient (bar). In the latter case the variation of permeability is explicitly taken into account. Diaphore then translates this fluid flow $\left(\mathrm{m}^{3} \cdot \mathrm{d}^{-1}\right)$ into velocity $\left(\mathrm{m} \cdot \mathrm{y}^{-1}\right)$. Reactions progress both in space and time. Results are displayed at time intervals chosen by the user.

\subsection{Calibration of the Calcite-Growth Kinetics}

The kinetics of fluid-rock interactions at the field scale in natural context is still an open question since the parameters that influence the reactions are numerous and often poorly constrained (fluid-flow velocity and water composition, nature and area of the mineral surfaces exposed to the flow of 
water, etc.). Some authors tried to calculate calcite precipitation rate (e.g., Renard et al., 2001) while others (e.g., Lee and Moorse, 1999) tried to understand how fractures can be sealed with an uniform calcite precipitation along the fracture. Lee et al. (1996) and Lee and Morse (1999) showed from experimental work that homogeneous sealing of a fracture by calcite can occur due to the high flow rate of over-saturated water.

Calcite precipitation is controlled by the reaction surface and by the saturation of water with respect to the mineral. Lee and Morse (1999) expressed the reaction rate $R\left(\mathrm{~mol} \cdot \mathrm{h}^{-1}\right)$ as a function of the reaction surface, $A_{b}$, and the average over-saturation index in the box experiment, $\Omega_{\mathrm{av}}$. The reaction rate is therefore given by the following equation:

$$
R=A_{b} \cdot k_{p}^{\prime} \cdot\left(\Omega_{a v} \cdot 1\right)^{n}
$$

where:

- $R\left(\mathrm{~mol} \cdot \mathrm{h}^{-1}\right)$ is the reaction rate;

- $A_{b}\left(\mathrm{~cm}^{2}\right)$ is the reaction surface;

- $k_{p}^{\prime}\left(\mathrm{mol} \cdot \mathrm{cm}^{-2} \cdot \mathrm{h}^{-1}\right)$ is a constant rate which depends on temperature and the $\mathrm{Mg} / \mathrm{Ca}$ ratio;

- $n$ (dimensionless) plays the role of the reaction order (Mucci and Morse, 1983);

- $\Omega_{a v}$ (dimensionless) is an average over-saturation state in the experimental box system, that corresponds to:

$$
\left(\frac{Q}{K_{e q}}\right)^{\alpha} \text { of the Equation (2). }
$$

The parameters of calcite growth rate represented in Diaphore were calibrated in order to adjust the experimental results provided by Lee and Morse (1999) (Fig. 3b). The values obtained are:

$$
\begin{aligned}
& k_{p}^{\prime}=1.7 \times 10^{-7} \mathrm{mmol} \cdot \mathrm{cm}^{-2} \cdot \mathrm{h}^{-1} ; \\
& \alpha=1.5 ; \\
& \beta=1 ;
\end{aligned}
$$

Values of $k_{p}^{\prime}\left(4.1 \cdot 10^{-7} \mathrm{mmol} \cdot \mathrm{cm}^{-2} \cdot \mathrm{h}^{-1}\right)$ and $n(2.3)$ obtained by Lee and Morse (1999) for the growth rate given by Equation (3) differ from $k_{p}$ and $\mathrm{n}$ because the average saturation rate $\Omega_{a v}$ is not calculated in the same way in Diaphore and in the formalism written by the cited authors.

\subsection{Parameters of the Simulations: Geometry, Water Composition and Flow Rate}

The simulations presented in this paper were designed to calculate the thickening rate of calcite deposits along the wall of open fractures or geodes. Cores sampled in the AIG-10 well are made of carbonate, marl and radiolarite (s.l.). Fractures were observed in carbonates. Their length and thickness are heterogeneous. Geodes appear too with an opening between less than $1 \mathrm{~mm}$ up to $2 \mathrm{~cm}$. Calcite precipitation occurred in the voids of these geodes and fractures.
The geochemical model was applied to a system that represents a $10 \mathrm{~cm}$-long fracture. The simulations were performed to quantify the time required for the sealing of fractures 1 to $20 \mathrm{~mm}$ thick. The geometry was modelled as a $2 \mathrm{D}(X, Z)$ grid system. Here we chose to represent the fracture plane oriented perpendicular to the $Z$-axis. Figure $3 \mathrm{c}$ shows the geometry of the system made of calcite $\left(100 \% \mathrm{CaCO}_{3}\right)$ and characterized by an initial porosity and reactive surface area set to a constant value in every part of the system.

For each computing time step the fluid composition and the rock properties are calculated for each grid element. Diaphore results are expressed as:

- the deposition rate of calcite on the fracture wall;

- the composition of the water (elements, expressed in $\left.\mathrm{mol} \cdot \mathrm{l}^{-1}\right)$.

The rate of sealing (\%), the thickness $(h)$ of precipitated calcite in the fracture in space and time, the rate of precipitation, as well as the time of sealing along the fracture, were also calculated.

Calcite precipitated from fluid passing through the voids observed in carbonates. The saturation index of the calcium carbonate phase, calculated using the PHREEQC geochemical code (Parkhurst and Appelo, 1999), showed that the fluids collected from -740 to $-1001 \mathrm{~m}$ during the pumping tests performed in the AIG-10 well are over-saturated with respect to calcite (Giurgea et al., 2004). In the present work, we focused only on the fluids coming from the hanging wall of the Aigion fault. The composition of the water collected during pumping tests at c.a. $740 \mathrm{~m}$ burial depth (Fig. 1 b) was measured by the Fluid Geochemistry Laboratory of INGV (Italy) (Table 1). The $\mathrm{pH}$ is equal to 8.48 and the temperature is $30^{\circ} \mathrm{C}$.

\section{TABLE 1} Geochemical analysis of a typical, relatively fresh water
from AIG-10 well (c.a. $-740 \mathrm{~m}$ ).

\begin{tabular}{c|c}
\hline \multicolumn{2}{c}{ Chemical element $\left(\mathbf{m g} \cdot \mathbf{l}^{-\mathbf{1}}\right)$} \\
\hline $\mathrm{K}$ & 5.2 \\
$\mathrm{Na}$ & 157.6 \\
$\mathrm{Ca}$ & 31.0 \\
$\mathrm{Mg}$ & 7.2 \\
$\mathrm{C}$ & 64.6 \\
$\mathrm{Cl}$ & 71.7 \\
\hline
\end{tabular}

The fluid composition given in Table 1 was used for the simulation of fluid-rock interaction. Seawater composition was used for comparison, as the chemical monitoring performed in the Aigion area through the CRL showed that, locally, slight mixing between seawater and fresh water could occur (Pizzino et al., 2004).

Permeability, connectivity and porosity values change across the damaged zones and fault core within the Aigion 
fault (Micarelli et al., 2003). However, these parameters are still poorly known because the work on fracture network is not completed. In the model presented here we worked at the local scale of one fracture, and the resulting permeability due to a complete fracture - network connectivity it out of scope. We focused on the sealing of fractures $10 \mathrm{~cm}$ long and 1 to $20 \mathrm{~mm}$ thick. In most of the simulations the rate of aqueous solution flowing through a fracture was maintained at a constant value. In this way, water-flow velocity is the main parameter that evolves through time, and as a function of flow rate and fracture thickness (see Appendix).

The fluid flow in the Aigion area can be characterized from data of the AIG-10 well. It has been also estimated by modelling at a regional scale (Tenchine, 2001; Jaubert, 2003). The well data show some overpressuring and provide a water-flow rate. The relief in the North Peloponnese is rather sharp and the mountains reach 2000 m only few tens of kilometers from the coast (Fig. 1). Therefore a strong south-north flow is driven by the topography. Jaubert (2003) showed by a 3D regional fluid-flow modelling that the pressure encountered in the well could be explained by a gravitydriven flow between the Pirgaki fault area (about $1000 \mathrm{~m}$ high) and the Aigion area (at sea level). Tenchine (2001) calculated that flow velocity ranges between $2 \cdot 10^{-3} \mathrm{~m} \cdot \mathrm{y}^{-1}$ and $1.5 \cdot 10^{-1} \mathrm{~m} \cdot \mathrm{y}^{-1}$. From fluid-flow rates measured during the pumping tests in the carbonate, the fluid velocity was estimated equal to $5 \cdot 10^{-8} \mathrm{~m} \cdot \mathrm{d}^{-1}$ in a fracture $1 \mathrm{~mm}$ thick, i.e., $1.8 \mathrm{~m} \cdot \mathrm{y}^{-1}$. As this estimation is very uncertain, we tested in the model a broad range of water-velocity values, between $2 \cdot 10^{-4} \mathrm{~m} \cdot \mathrm{y}^{-1}$ and $2 \cdot 10^{+2} \mathrm{~m} \cdot \mathrm{y}^{-1}$. In the model, either fluid flow or pressure gradient can be imposed. In the Aigion area both boundary conditions can be used, according to the scale of investigation: at regional scale the fluid flow is driven by the hydraulic head related to the relief ( imposed pressure gradient). Nevertheless, the available water quantity depends also on the seasonal rain ( imposed fluid flow). At the scale of one fracture it is more difficult to decide on the correct type of boundary condition, therefore two types of simulation were run.

The water-flow velocity depends on flow input condition and on the fracture thickness, as depicted in Figure 4 and in the Appendix. With imposed flow rate, water circulation grows faster as the fracture becomes narrower, whereas with imposed pressure-gradient water velocity increases with fracture thickness. Three sets of simulation tests were performed in order to examine respectively the influence of flow rate (from $5 \cdot 10^{-8}$ to $5 \cdot 10^{-4} \mathrm{~m}^{3} \cdot \mathrm{d}^{-1}$ ), of pressure gradient (from $5 \cdot 10^{-8}$ to $5 \cdot 10^{-4} \mathrm{bar}$ ), and of the composition of water (sampled water $v s$. seawater). The influence of the initial fracture thickness (from $1 \mathrm{~mm}$ up to $2 \mathrm{~cm}$ ) was also considered (parameter b, in the Appendix).

\section{MODELLING RESULTS}

\subsection{Reference Test}

The first numerical experiment, which will serve as a reference, shows the progression in time of calcite precipitation, along a $10 \mathrm{~cm}$ long and $1 \mathrm{~mm}$ thick fracture (Fig. 5).
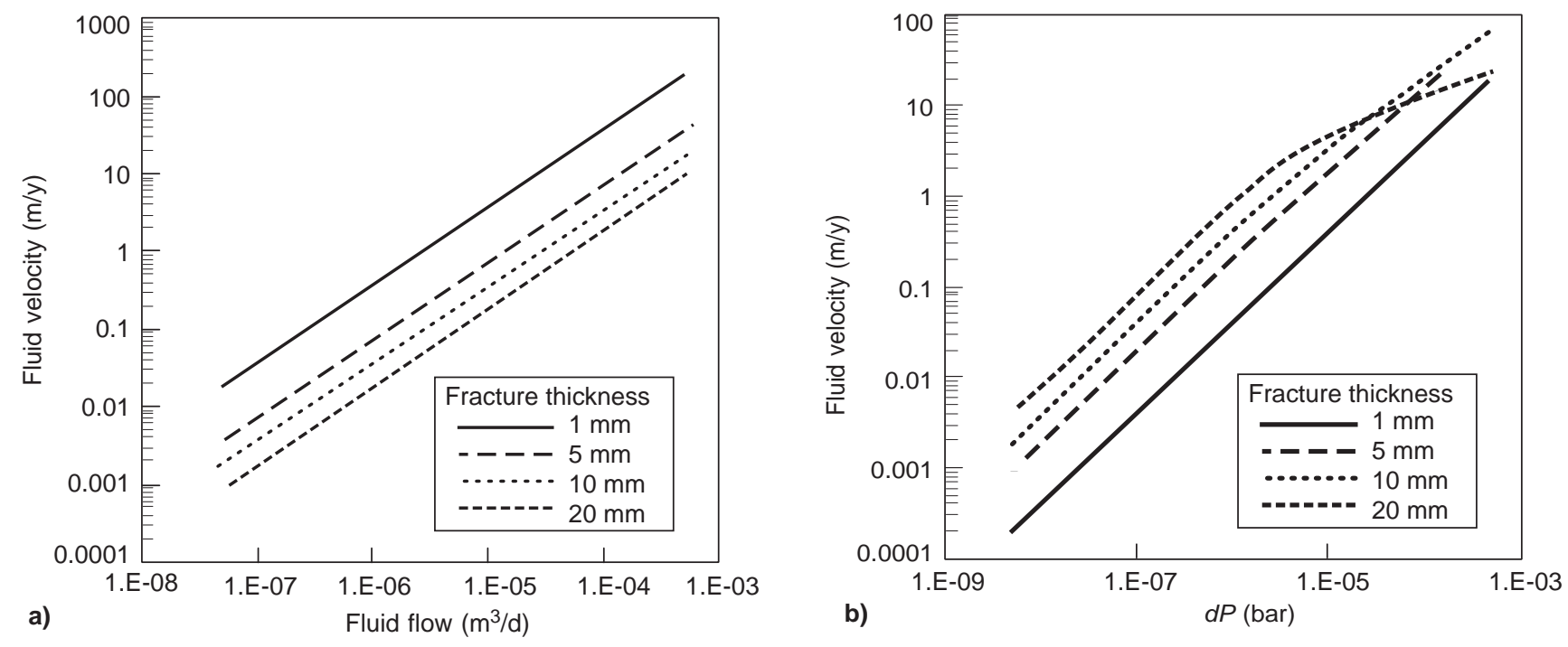

Figure 4

Velocity in four fractures, respectively 1, 5, 10 and $20 \mathrm{~mm}$ thick (initial aperture, $b$ ), in function of the fluid-flow value.

a) fluid-flow velocity versus flow rate.

b) fluid-flow velocity versus pressure gradient. 

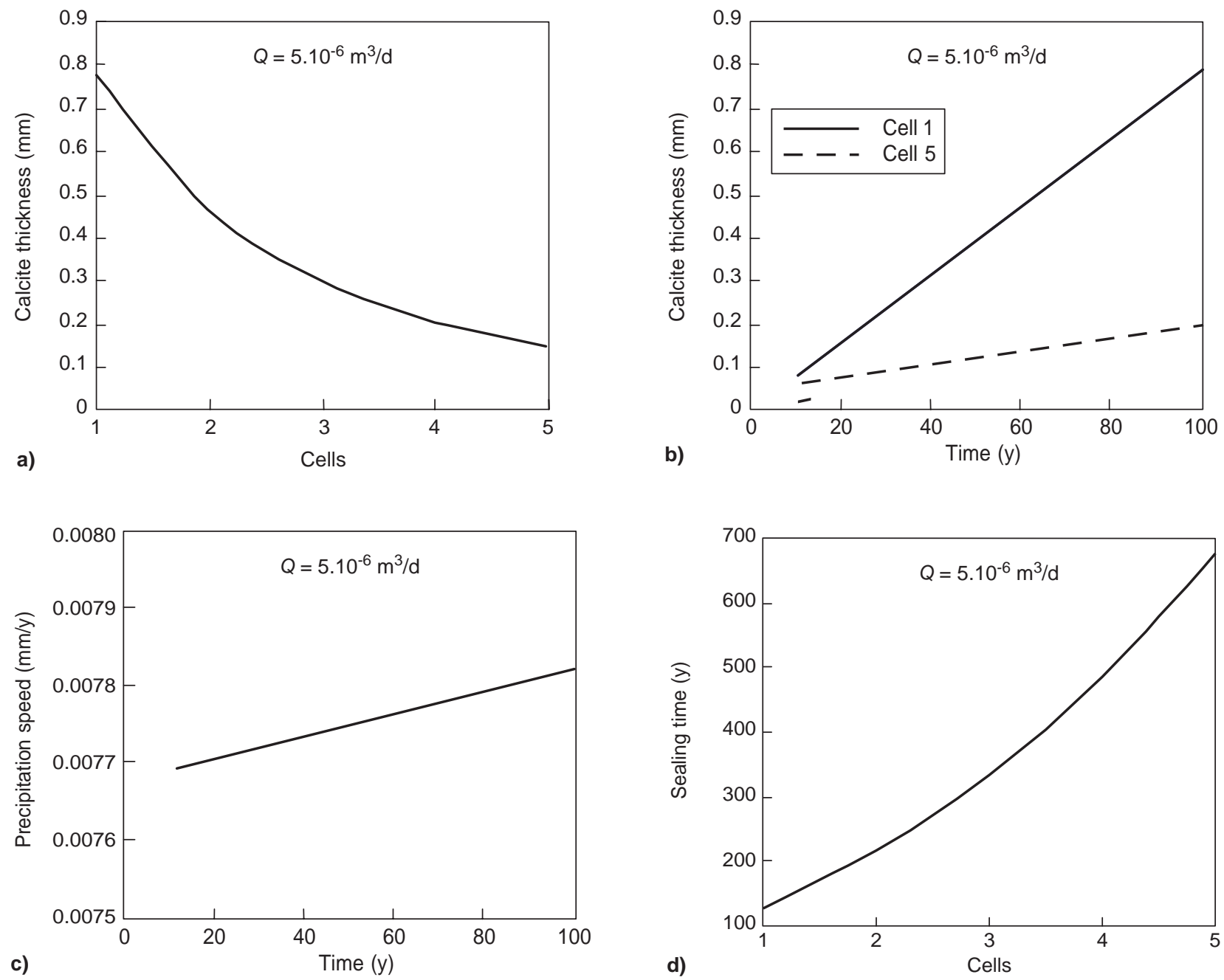

Figure 5

Reference simulation: sealing of a fracture $10 \mathrm{~cm}$ long, $1 \mathrm{~mm}$ thick and crossed by a flow rate equal to $5 \cdot 10^{-6} \mathrm{~m}^{3} \cdot \mathrm{day}^{-1}$, corresponding to a velocity of $1.8 \mathrm{~m} \cdot \mathrm{yr}^{-1}$.

a) thickness of calcite precipitated along the fracture, after $100 \mathrm{y}$.

b) thickness of calcite precipitated versus time in the inlet (bold line) and outlet (point line).

c) flow velocity at the inlet versus time.

d) sealing time along the fracture.

Fluid-flow rate (parameter $\phi$, in the Appendix) was maintained constant through the fracture, with a value equal to $5 \cdot 10^{-6} \mathrm{~m}^{3} \cdot \mathrm{d}^{-1}$. Table 2 gives the composition of water taken into account in the simulation. The initial composition is also the composition of water that invades the system at its inlet. The second composition is a typical composition calculated in the course of the calcite-growth process.

In the conditions of the simulation, calcite precipitation along the fracture is heterogeneous (Fig. 5a). The deposition rate varies along the fracture length because the aqueous solution progressively approaches equilibrium. The computed thickness of calcite $(h)$ precipitated through time is displayed in Figure 5b for the inlet (bold, continuous line) and the outlet (dashed line) of the considered fracture. Calcite precipitation in any place along the $X$-axis depends linearly on time. The fluid-flow velocity (parameter $u$, in the Appendix) varies also through time, it increases during the numerical experiment due to the decrease of the fracture thickness (the fluid flow rate remains constant by hypothesis). Figure $5 \mathrm{~d}$ shows an estimation of the time required to completely seal a part of fracture based on the calcite growth computed by Diaphore. For the inlet (cell no. 1) the time required is $135 \mathrm{y}$, whereas it reaches $680 \mathrm{y}$ for the outlet (cell no. 5). In the simple case of a single fracture there is no alternative pathway and a $100 \%$ sealed inlet prevents the outlet sealing. In a real fracture network with numerous 
TABLE 2

Simulation of the AIG-10 water composition in the course of calcite precipitation

\begin{tabular}{l|c|c|}
\hline \multirow{2}{*}{} & \multicolumn{2}{|c|}{ Molality $\left(\mathrm{mol} / \mathrm{kgH}_{2} \mathrm{O}\right)$} \\
& Initial & During prec. \\
\hline $\mathrm{Na}$ & $6.85287 \mathrm{E}-03$ & $6.85287 \mathrm{E}-03$ \\
$\mathrm{Cl}$ & $2.21666 \mathrm{E}-03$ & $2.21666 \mathrm{E}-03$ \\
$\mathrm{~K}$ & $1.33020 \mathrm{E}-04$ & $1.33020 \mathrm{E}-04$ \\
$\mathrm{Ca}$ & $7.64676 \mathrm{E}-04$ & $3.78039 \mathrm{E}-04$ \\
$\mathrm{Mg}$ & $2.96040 \mathrm{E}-04$ & $2.96040 \mathrm{E}-04$ \\
$\mathrm{C}$ & $7.03681 \mathrm{E}-03$ & $6.28228 \mathrm{E}-03$ \\
$\mathrm{pH}$ & 7.8 & 7.75 \\
$p \mathrm{CO}_{2}$ & 0.007 & 0.007 \\
\hline
\end{tabular}

\begin{tabular}{l|c|c}
\hline Species & $\begin{array}{c}\text { Activity } \\
\text { initial }\end{array}$ & During prec. \\
\hline $\mathrm{H}_{2} \mathrm{O}$ & $9.99652 \mathrm{E}-01$ & $9.99689 \mathrm{E}-01$ \\
$\mathrm{H}^{+}$ & $1.58489 \mathrm{E}-08$ & $1.76346 \mathrm{E}-08$ \\
$\mathrm{~K}^{+}$ & $1.19554 \mathrm{E}-04$ & $1.20194 \mathrm{E}-04$ \\
$\mathrm{Na}^{+}$ & $6.17399 \mathrm{E}-03$ & $6.20570 \mathrm{E}-03$ \\
$\mathrm{Ca}^{2+}$ & $4.71195 \mathrm{E}-04$ & $2.39561 \mathrm{E}-04$ \\
$\mathrm{Mg}^{2+}$ & $1.87933 \mathrm{E}-04$ & $1.92956 \mathrm{E}-04$ \\
$\mathrm{HCO}_{3}{ }^{-}$ & $6.05690 \mathrm{E}-03$ & $5.44379 \mathrm{E}-03$ \\
$\mathrm{Cl}^{-}$ & $1.99066 \mathrm{E}-03$ & $2.00130 \mathrm{E}-03$ \\
$\mathrm{OH}^{-}$ & $9.19220 \mathrm{E}-07$ & $8.26169 \mathrm{E}-07$ \\
$\mathrm{KCl}^{-}$ & $2.66000 \mathrm{E}-09$ & $2.69000 \mathrm{E}-09$ \\
$\mathrm{NaCl}^{-}$ & $1.82620 \mathrm{E}-06$ & $1.84540 \mathrm{E}-06$ \\
$\mathrm{NaCO}_{3}{ }^{-}$ & $2.95000 \mathrm{E}-06$ & $2.39500 \mathrm{E}-06$ \\
$\mathrm{CaCO}_{3}$ & $1.71419 \mathrm{E}-05$ & $7.03980 \mathrm{E}-06$ \\
$\mathrm{CaHCO}_{3}{ }^{+}$ & $4.39912 \mathrm{E}-05$ & $2.01017 \mathrm{E}-05$ \\
$\mathrm{MgCO}_{3}$ & $9.43273 \mathrm{E}-06$ & $7.82311 \mathrm{E}-06$ \\
$\mathrm{MgHCO}_{3}{ }^{+}$ & $1.21373 \mathrm{E}-05$ & $1.12003 \mathrm{E}-05$ \\
$\mathrm{CO}_{3}{ }^{--}$ & $1.99115 \mathrm{E}-05$ & $1.60839 \mathrm{E}-05$ \\
$\mathrm{H}_{2} \mathrm{CO}_{3}$ & $2.07539 \mathrm{E}-04$ & $2.07546 \mathrm{E}-04$ \\
${\mathrm{Mg}(\mathrm{OH})^{+}}_{\mathrm{Ca}^{+}(\mathrm{OH})^{+}}$ & $7.01980 \mathrm{E}-08$ & $6.47786 \mathrm{E}-08$ \\
$\left(\mathrm{Ca}^{2+}\right) \cdot\left(\mathrm{CO}_{3}{ }^{2-}\right)$ & $4.54000 \mathrm{E}-10$ & $2.07000 \mathrm{E}-10$ \\
${\log (Q / K) \mathrm{calcite}^{-}}$ & $9.38222 \mathrm{E}-09$ & $3.85306 \mathrm{E}-09$ \\
\hline
\end{tabular}

connections, the complete sealing of a long fracture could be reached by a more complicated migration pathway. The preservation of open voids, observed from theAIG-10 faultrelated core, could be nevertheless explained by the sealing of the migration pathways that give access to the main fluid flow.

In conclusion, the modelling showed that the time required to seal a $1 \mathrm{~mm}$ thick fracture in the conditions that prevail in AIG-10 is in the range of a few hundred years (Fig. 5d).

\subsection{Influence of Both Fluid-Flow Rate and Fracture Thickness on the Sealing Rate}

\subsubsection{Flow Rate}

Another set of simulations was carried out to examine the impact of the fluid-flow rate. As mentioned above the fluid flow from the AIG-10 well, that is eruptive, was measured (Cornet et al., 2004; Giurgea et al., 2004). Nevertheless, the fluid flow through an individual fracture is likely to vary in a large range of values. The open part of the borehole is about $300 \mathrm{~m}$ thick (between 700 and $1000 \mathrm{~m}$ depth) and therefore the global flow through this open part has been measured. In addition the flow is also known to change yearly due to seasonal variations (Cornet, personal communication).
With a low fluid flow rate, 100 times lower than within the reference case, calcite precipitation is about 30 times slower (Fig. 6a). The deposit of calcite is also much more heterogeneous along the $X$-axis, the calcite deposit is thick at the inlet but extremely thin further along in the flow direction. After $100 \mathrm{y}$ the thickness of calcite deposit is $0.025 \mathrm{~mm}$ at the inlet $(0.76 \mathrm{~mm}$ in the reference case $)$ and close to zero at the outlet $(0.15 \mathrm{~mm}$ in the reference case). The sealing process, computed as previously by multiplying the rate of growth by the thickness of the fracture, takes approximately $4000 \mathrm{y}$ at the inlet. At the outlet, $300000 \mathrm{y}$ would be necessary (Fig. 6b). Note that such a delay is longer than the age of Aigion fault. Within this assumption of low fluid flow, fluid reaches saturation with respect to calcite inside the modelled system itself, because of the long time of residence in the fracture. As a result, the precipitation is slowed down in space and time.

The high impact of a low flow rate illustrates that the formation of calcite in the fracture is strongly dependent on the transfer of dissolved elements, which is certainly a mechanism to be evaluated at the regional scale. Moreover, the profile of calcite cementation in the veins is affected. The precipitation occurs much more locally at the point where the fluid can invade the fracture.

Other computations were done with a high fluid flow rate. An increase of the fluid flow rate results in the increase of 

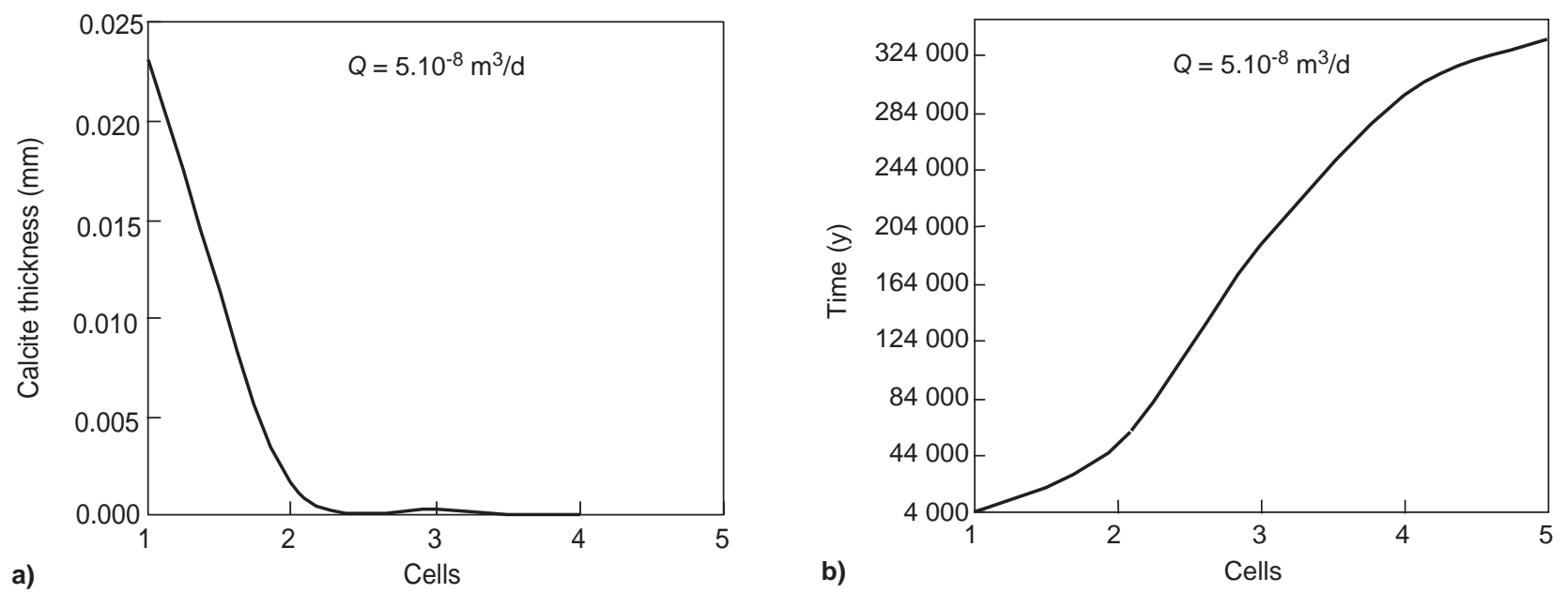

Figure 6

Simulations: sealing of a fracture $10 \mathrm{~cm}$ long, $1 \mathrm{~mm}$ thick and crossed by a flow rate equal to $5 \cdot 10^{-8} \mathrm{~m}^{3} \cdot \mathrm{day}^{-1}$, corresponding to a water velocity of $0.2 \mathrm{~m} \cdot \mathrm{y}^{-1}$.

a) thickness of calcite precipitated along the fracture, after $100 \mathrm{y}$.

b) sealing time along the fracture.
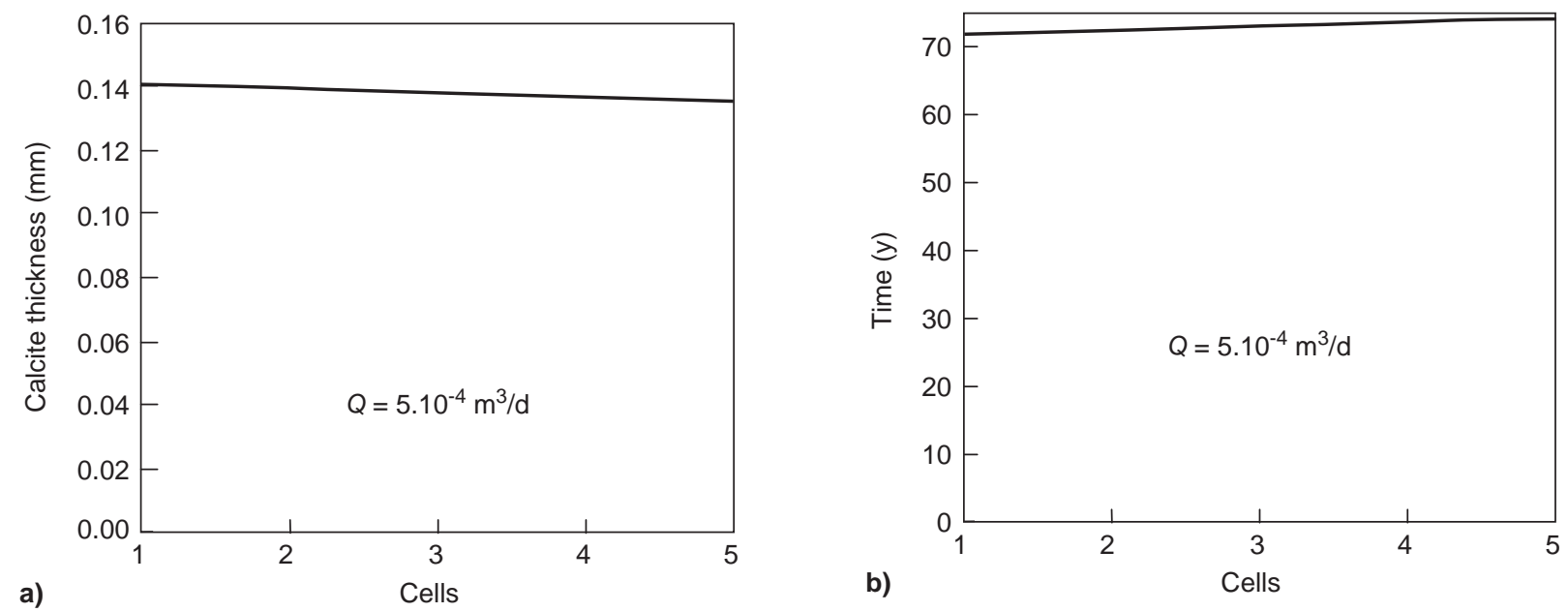

Figure 7

Simulations: sealing of a fracture $10 \mathrm{~cm}$ long, $1 \mathrm{~mm}$ thick and crossed by a flow rate equal to $5 \cdot 10^{-4} \mathrm{~m}^{3} \cdot \mathrm{day}^{-1}$, corresponding to a water velocity of $200 \mathrm{~m} \cdot \mathrm{y}^{-1}$.

a) thickness of calcite precipitated along the fracture, after $10 \mathrm{y}$.

b) sealing time along the fracture.

calcite precipitation. Figure 7a shows the results with a fluid flow increased by a factor of $100\left(5.010^{-4} \mathrm{~m}^{3} \cdot \mathrm{d}^{-1}\right)$. In this case, precipitation becomes almost homogeneous along the fracture (Fig. 7a). The fluid velocity in the fracture is now equal to $200 \mathrm{~m} \cdot \mathrm{y}^{-1}$. Results are given after $10 \mathrm{y}$ of simulation because the fracture is sealed before $100 \mathrm{y}$. The thickness of the calcite deposit is equal to $0.14 \mathrm{~mm}$ after $10 \mathrm{y}$ in the inlet (it was $0.08 \mathrm{~mm}$ in the reference case). The precipitation rate is faster. The sealing time is shorter, c.a. 72 y (Fig. 7b).
The reaction is fast: a high fluid velocity renews dissolved species quickly and helps to maintain a high over-saturation rate with respect to calcite, and consequently high growth rates all along the system. The precipitation and the sealing time are also much more homogeneous.

\subsubsection{Fracture Thickness}

A specific set of simulations was performed by increasing the initial fracture thickness (parameter $b$, in Appendix). 
The new fracture is $10 \mathrm{~cm}$ long and $20 \mathrm{~mm}$ thick. It is crossed by a fluid-flow rate equal to $5 \cdot 10^{-6} \mathrm{~m}^{3} \cdot \mathrm{d}^{-1}$, as for the reference test. Calcite precipitation is abundant on $2.4 \mathrm{~mm}$ close to the inlet (Fig. 8a) and higher than in the $1 \mathrm{~mm}$ thick fracture where the deposit thickness was found to be equal to $0.8 \mathrm{~mm}$ (Fig. 5a). The outlet is not affected by precipitation. The fluid velocity is relatively lower in this thick fracture, but the fluidto-rock interaction ratio is higher because of the void space. As the residence time of the fluid is much longer, the oversaturation value vanishes at a short distance from the inlet. The time needed for sealing a thick fracture depends on the position from the inlet and ranges between $800 \mathrm{y}$ and $2 \mathrm{My}$
(Fig. 8b), much longer than the time needed for the $1 \mathrm{~mm}$ thick fracture (100 to $700 \mathrm{y}$ ) (Fig. 5c). In terms of vein occlusion, the thickness of the calcite deposit is not proportional to the thickness of the fracture. With a constant flow rate, sealing time depends on both fracture thickness and fluid velocity, the second being also influenced by the fracture thickness.

\subsubsection{Conclusion on the Influence of Flow Rate}

Figure 9a shows the evolution of the calcite thickness in fractures initially 1, 2, 10 and $20 \mathrm{~mm}$ width as a function of the flow-rate value. Precipitation increases with flow rate.
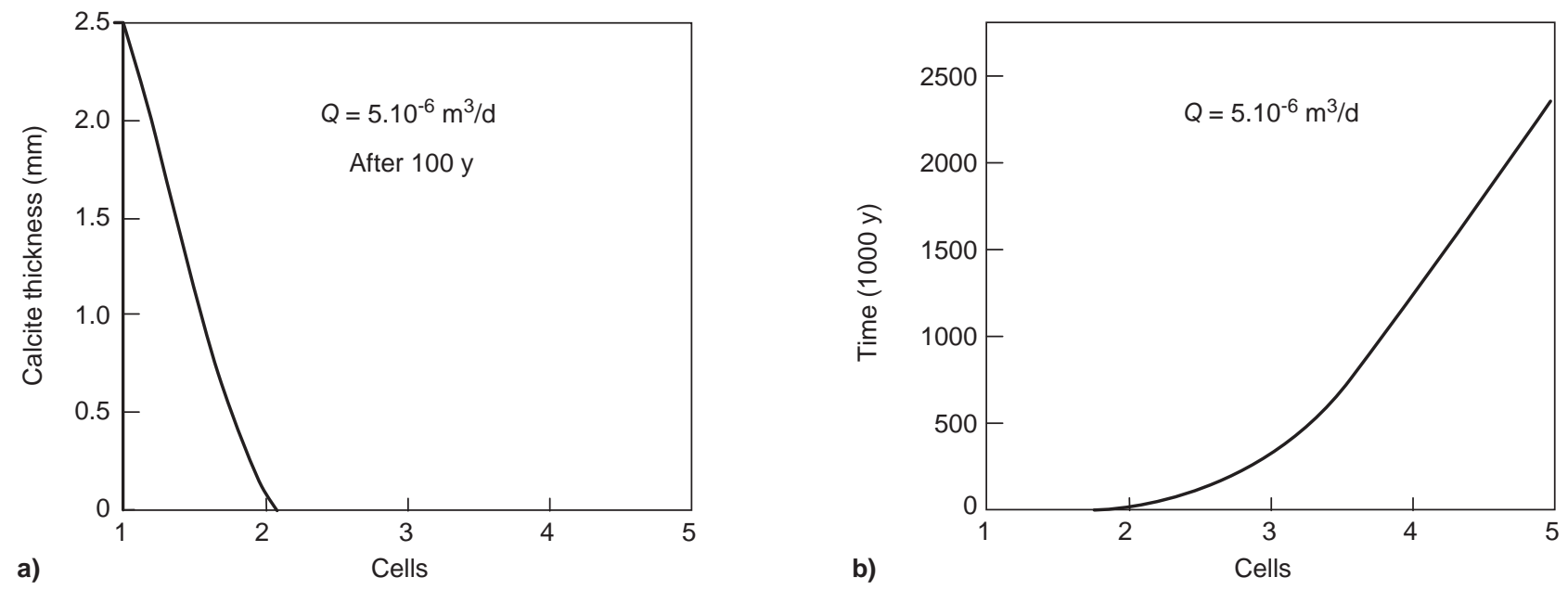

Figure 8

Simulations: sealing of a fracture $10 \mathrm{~cm}$ long, $20 \mathrm{~mm}$ thick and crossed by a flow rate equal to $5 \cdot 10^{-6} \mathrm{~m}^{3} \cdot$ day ${ }^{-1}$, corresponding to a water velocity of $2 \cdot 10^{-3} \mathrm{~m} \cdot \mathrm{y}^{-1}$.

a) thickness of calcite precipitated along the fracture, after $100 \mathrm{y}$.

b) sealing time along the fracture.

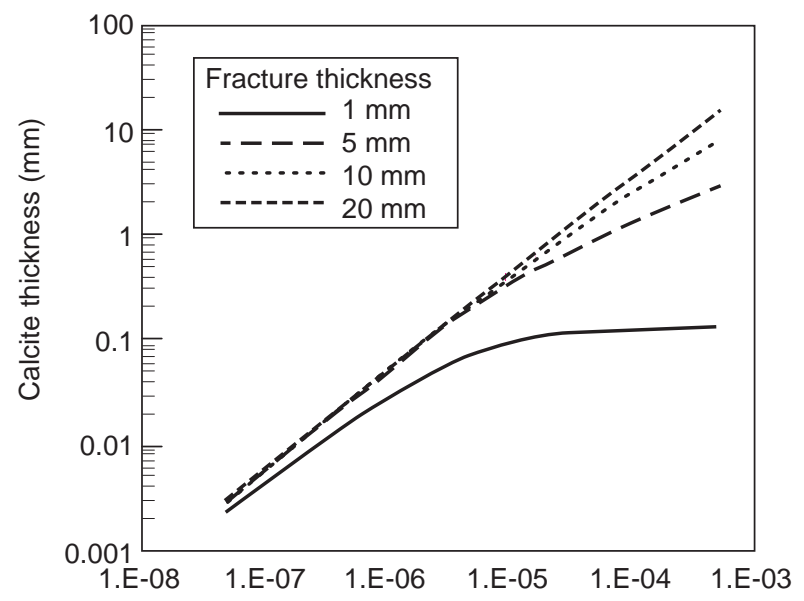

a)

Fluid flow rate $\left(\mathrm{m}^{3} / \mathrm{d}\right)$

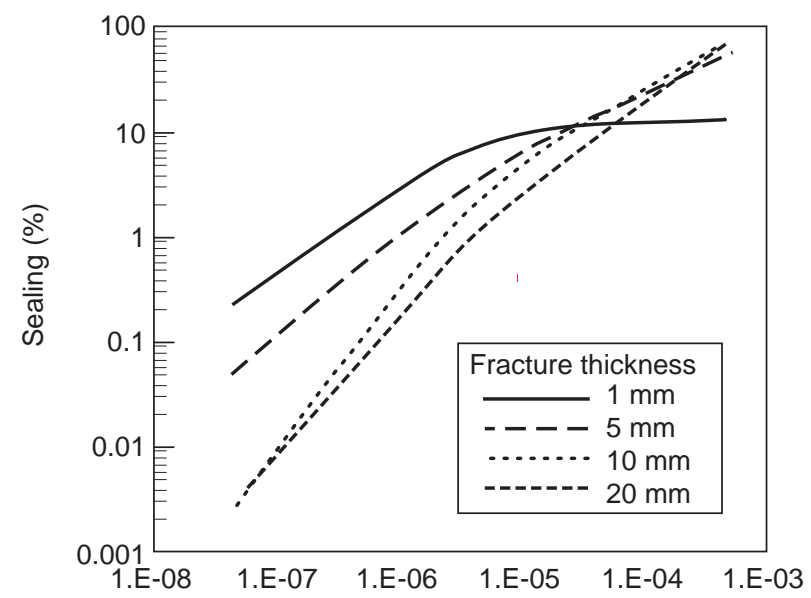

b)

Figure 9

Synthesis: sealing fracture 1 to $20 \mathrm{~mm}$ thick versus flow rate.

a) thickness of calcite precipitated versus flow rate in each fracture 1, 5, 10 and $20 \mathrm{~mm}$ thick.

b) sealing rate versus flow rate in each fracture 1, 5, 10 and $20 \mathrm{~mm}$ thick. 

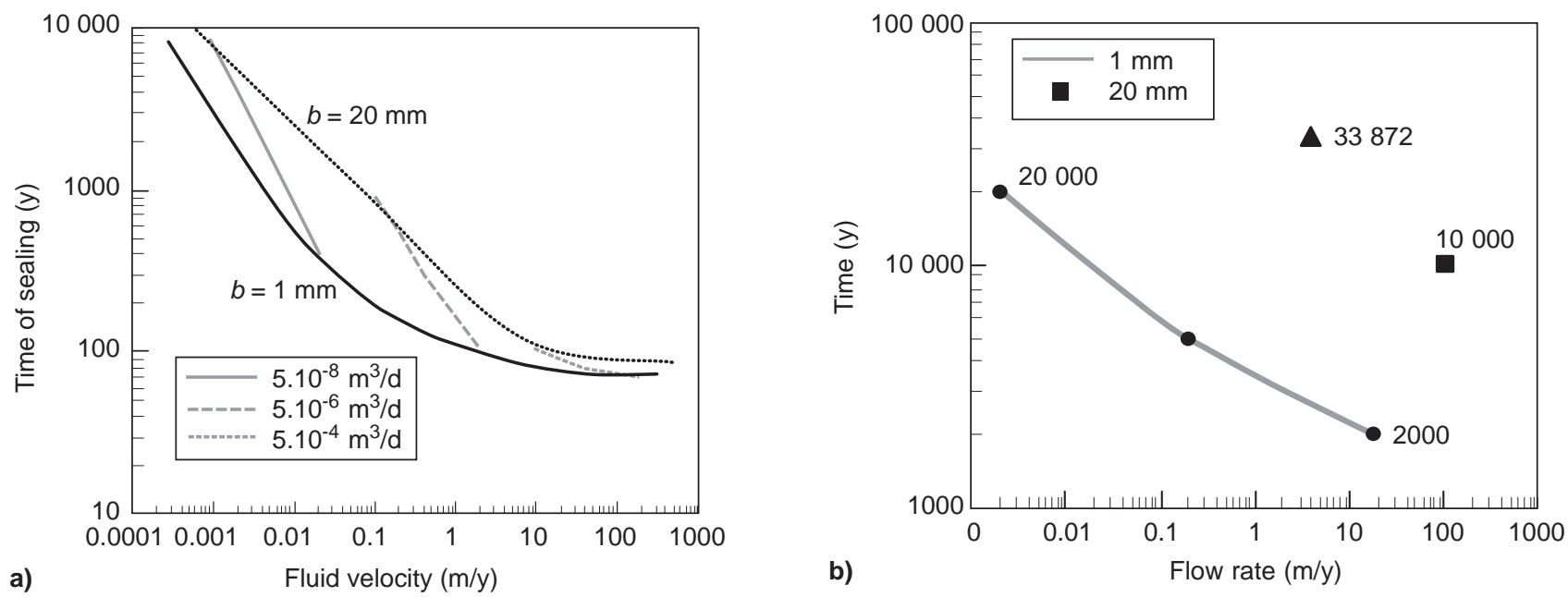

Figure 10

Synthesis: sealing time in function of fracture thickness and fluid flow (flow rate and pressure gradient).

a) time of sealing a fracture 1 to $20 \mathrm{~mm}$ thick in function of the flow-rate value.

b) time of sealing fracture 1 to $20 \mathrm{~mm}$ thick in function of the pressure gradient.

Cross section of a fracture $1 \mathrm{~mm}$ thick
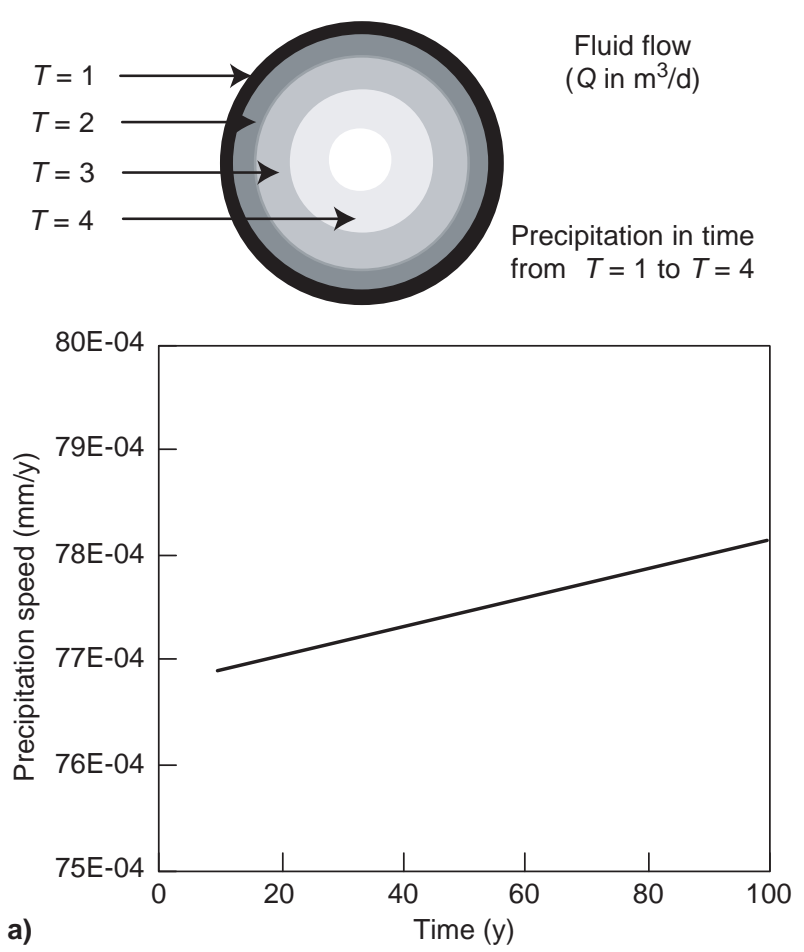

Cross section of a fracture $1 \mathrm{~mm}$ thick
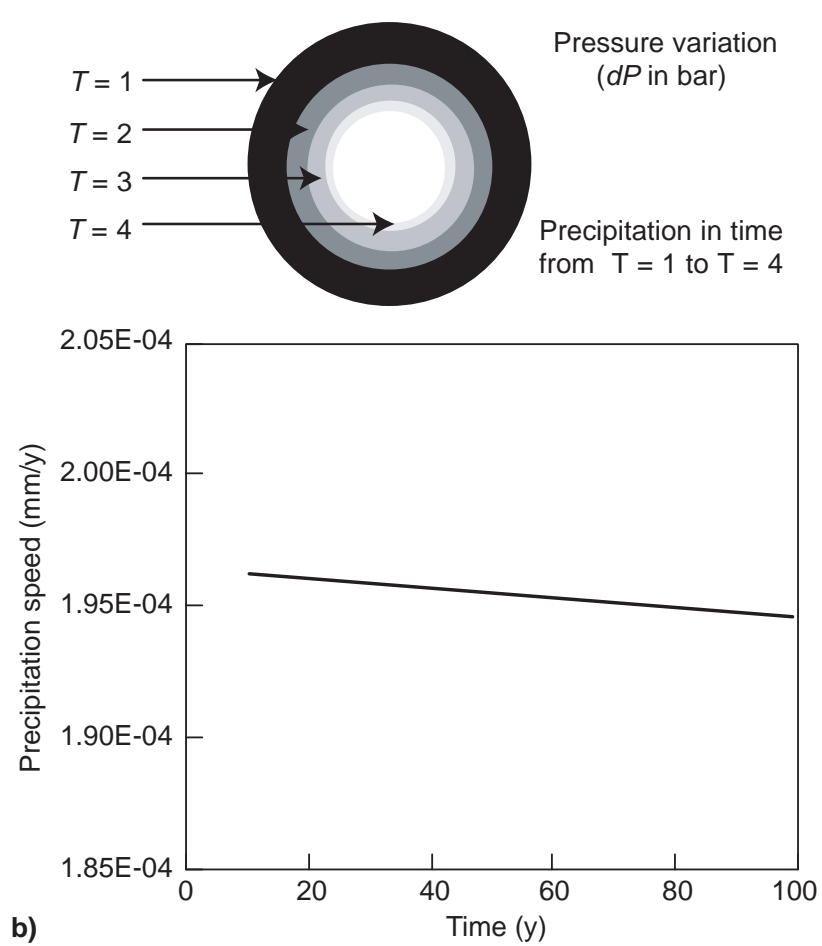

Figure 11

Evolution of the precipitation in a fracture $1 \mathrm{~mm}$ thick crossed by a): a fluid with a flow rate of $5 \cdot 10^{-6} \mathrm{~m}^{3} \cdot$ day $^{-1}$, and b): by a fluid with determined by a pressure gradient of $5 \cdot 10^{-6}$ bar. 
Results give a linear relation between the thickness of calcite and fluid-flow rate, except for the thinnest fracture that shows a stabilization at strong fluid flow. This kind of evolution is responsible for the inversion of the relationship between the sealing rate and the fluid-flow rate, as initial fracture thickness changes (Fig. 9b). In general, the sealingrate value is higher in a narrow fracture since the void to be sealed is relatively small. At a certain high fluid-flow rate, a thick fracture has a relatively higher sealing rate. Flow velocity increases with fluid flow. This fluid velocity can be so fast in a narrow fracture that the precipitation drops. There is a stage for which the calcite precipitation is slower than flow velocity. Whatever the details of this behaviour, the time necessary for sealing a fracture 1 to $20 \mathrm{~mm}$ thick was calculated to be between 70 and $10000 \mathrm{y}$ (Fig. 10a). This result means that the fractured network of a rock formation can be modified at the time scale of several centuries.

\subsubsection{Influence of the Pressure Gradient}

Another set of simulations was designed to quantify the influence of the pressure-gradient variation on the fracture sealing. They were carried out at constant pressure gradient, with values between $5 \cdot 10^{-8}$ and $5 \cdot 10^{-4}$ bar corresponding to a flow velocity between $2 \cdot 10^{-4}$ and $2 \cdot 10^{+2} \mathrm{~m} \cdot \mathrm{y}^{-1}$.

The resulting time for sealing a $1 \mathrm{~mm}$ thick fracture was calculated at between 2000 and 20000 y (Fig. 10b). These values are higher than those obtained at equivalent imposed flow rates (Fig. 10a).

\subsection{Comparison of the Two Types of Flow Boundary conditions}

The water flow in a rock can be expressed either as a flow rate, or as the effect of a pressure gradient. The two parameters are linked, at the macroscopic scale, by Darcy's law.

Fluid velocity depends on the fracture thickness. At constant flow rate the velocity is higher in a narrow fracture than in a thick one. Narrow fractures are sealed rather quickly, first because of their smaller amount of void, and second because of the increase of fluid velocity with time (Fig. 11a). On the other hand, at constant pressure gradient, fluid velocity is higher in a thick fracture than in a narrow one. This means that fluid velocity decreases with fracture thickness. As a result, the rate of fracture sealing also slows down with time (Fig. 11b). Depending on how fluid flows, fractures can be more or less quickly sealed.

\subsection{Influence of the Water Composition}

The Aigion well is located very close to the sea shore (Fig. 1). Northward from Aigion, the Gulf of Corinth is less than $400 \mathrm{~m}$ deep but it reaches $860 \mathrm{~m}$ in the central part.

TABLE 3

Simulation of the seawater composition in the course of calcite dissolution

\begin{tabular}{l|c|c|}
\hline \multirow{2}{*}{} & \multicolumn{2}{|c|}{ Molality $\left(\mathrm{mol} / \mathrm{kgH}_{2} \mathrm{O}\right)$} \\
& Initial & During prec. \\
\hline $\mathrm{Na}$ & $4.99956 \mathrm{E}-01$ & $4.99956 \mathrm{E}-01$ \\
$\mathrm{Cl}$ & $6.43805 \mathrm{E}-01$ & $6.43805 \mathrm{E}-01$ \\
$\mathrm{~K}$ & $1.50183 \mathrm{E}-02$ & $1.50183 \mathrm{E}-02$ \\
$\mathrm{Ca}$ & $1.16061 \mathrm{E}-02$ & $1.17269 \mathrm{E}-02$ \\
$\mathrm{Mg}$ & $5.40410 \mathrm{E}-02$ & $5.40410 \mathrm{E}-02$ \\
$\mathrm{C}$ & $2.66843 \mathrm{E}-03$ & $2.90087 \mathrm{E}-03$ \\
$\mathrm{pH}$ & 7 & 7.04 \\
$\mathrm{pCO}$ & 0.01 & 0.01 \\
\hline
\end{tabular}

\begin{tabular}{l|c|c}
\hline Species & $\begin{array}{c}\text { Activity } \\
\text { initial }\end{array}$ & During prec. \\
\hline $\mathrm{H}_{2} \mathrm{O}$ & $9.77057 \mathrm{E}-01$ & $9.77048 \mathrm{E}-01$ \\
$\mathrm{H}^{+}$ & $1.00000 \mathrm{E}-07$ & $9.14040 \mathrm{E}-08$ \\
$\mathrm{~K}^{+}$ & $9.34538 \mathrm{E}-03$ & $9.34513 \mathrm{E}-03$ \\
$\mathrm{Na}^{+}$ & $3.23980 \mathrm{E}-01$ & $3.23976 \mathrm{E}-01$ \\
$\mathrm{Ca}^{2+}$ & $2.77861 \mathrm{E}-03$ & $2.80520 \mathrm{E}-03$ \\
$\mathrm{Mg}^{2+}$ & $1.67179 \mathrm{E}-02$ & $1.67052 \mathrm{E}-02$ \\
$\mathrm{HCO}_{3}{ }^{-}$ & $1.34035 \mathrm{E}-03$ & $1.46638 \mathrm{E}-03$ \\
$\mathrm{Cl}^{-}$ & $3.91533 \mathrm{E}-01$ & $3.91523 \mathrm{E}-01$ \\
$\mathrm{OH}^{-}$ & $1.42393 \mathrm{E}-07$ & $1.55783 \mathrm{E}-07$ \\
$\mathrm{KCl}^{-}$ & $4.09208 \mathrm{E}-05$ & $4.09186 \mathrm{E}-05$ \\
$\mathrm{NaCl}^{-}$ & $1.88480 \mathrm{E}-02$ & $1.88472 \mathrm{E}-02$ \\
$\mathrm{NaCO}_{3}{ }^{-}$ & $5.42952 \mathrm{E}-06$ & $6.49862 \mathrm{E}-06$ \\
$\mathrm{CaCO}_{3}$ & $3.54529 \mathrm{E}-06$ & $4.28404 \mathrm{E}-06$ \\
$\mathrm{CaHCO}_{3}{ }^{+}$ & $5.74063 \mathrm{E}-05$ & $6.34055 \mathrm{E}-05$ \\
$\mathrm{MgCO}_{3}$ & $2.94295 \mathrm{E}-05$ & $3.51980 \mathrm{E}-05$ \\
$\mathrm{MgHCO}_{3}{ }^{+}$ & $2.38929 \mathrm{E}-04$ & $2.61198 \mathrm{E}-04$ \\
$\mathrm{CO}_{3}{ }^{--}$ & $6.98347 \mathrm{E}-07$ & $8.35866 \mathrm{E}-07$ \\
$\mathrm{H} 2 \mathrm{CO}_{3}$ & $2.89778 \mathrm{E}-04$ & $2.89775 \mathrm{E}-04$ \\
${\mathrm{Mg}(\mathrm{OH})^{+}}_{\left.\mathrm{Ca}^{+} \mathrm{OH}\right)^{+}}$ & $9.67330 \mathrm{E}-07$ & $1.05749 \mathrm{E}-06$ \\
$\left(\mathrm{Ca}^{2+}\right) \cdot\left(\mathrm{CO}_{3}{ }^{2-}\right)$ & $4.14600 \mathrm{E}-10$ & $4.57927 \mathrm{E}-10$ \\
${\log (Q / K) \mathrm{calcite}^{-}}$ & $1.94043 \mathrm{E}-09$ & $2.34477 \mathrm{E}-09$ \\
& -0.191 & -0.109 \\
\hline
\end{tabular}


Therefore the infiltration of seawater down to the pre-rift sequence in the hanging wall of the fault bordering the Gulf is probable despite it not being permanent over time (Rettenmaier et al., 2004). In order to test the influence of such a possible contamination of the seawater, another set of simulations was carried out with a flow of seawater instead of the fresh water sampled at Aigion during the drilling operations in September 2002.

Table 3 shows that at the same $p \mathrm{CO}_{2}$ value as considered previously $(0.007$ bar, a value that fits relatively well the alkalinity measured in the sample from AIG-10 well), seawater still precipitates calcite. However, a slight increase of $p \mathrm{CO}_{2}$, up to 0.01 bar, leads to a fluid that is capable of dissolving calcite. Such an increase in the $p \mathrm{CO}_{2}$ value is very probable in the tip of the Aigion fault, as strong overpressuring was measured and its footwall. In addition, the regional survey on the $\mathrm{CO}_{2}$ content in the ground water in the area (from springs and shallow wells) has shown the high variability of this $\mathrm{CO}_{2}$ content (Pizzino et al., 2004).

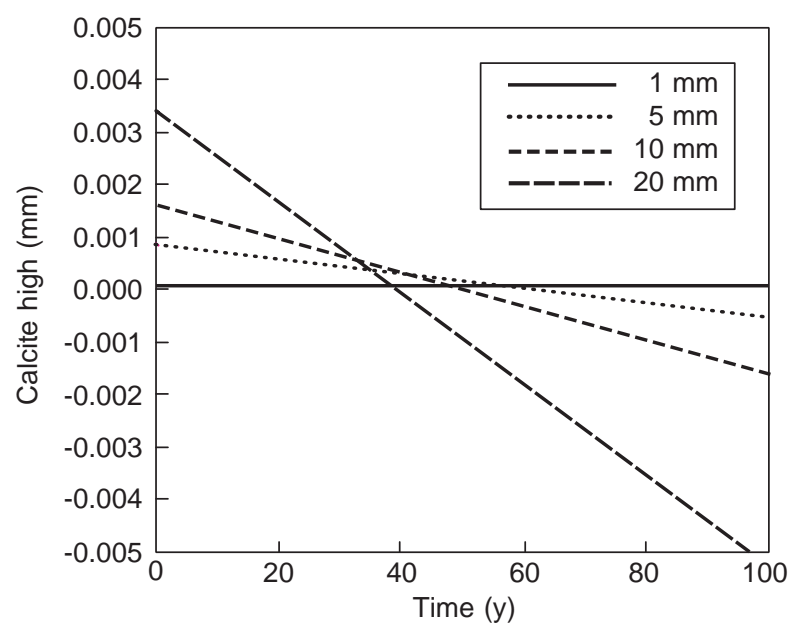

Figure 12

Thickness of calcite precipitated along the fracture $10 \mathrm{~cm}$ long and 1 to $20 \mathrm{~mm}$ thick crossed by fluid of seawater composition flowing with a pressure gradient of $1 \cdot 10^{-7}$ bar corresponding to a water velocity of 0.004 to $0.8 \mathrm{~m} \cdot \mathrm{y}^{-1}$.

It was assumed that a fluid with the seawater composition, at $p \mathrm{CO}_{2} 0.01 \mathrm{bar}$, crosses fractures in the range 1 to $20 \mathrm{~mm}$ thick, with a pressure gradient of $7.10^{-7}$ bar between the inlet and the outlet. The corresponding fluid velocity is $0.08 \mathrm{~m} . \mathrm{y}^{-1}$ for a thick fracture and to $0.004 \mathrm{~m} \cdot \mathrm{y}^{-1}$ for a thin fracture. Results show that in this specific case both precipitation and dissolution of calcite successively occur through time (Fig. 12). Figure 12 illustrates the thickness of the calcite deposit at the inlet versus time in the four fractures $(1,5,10$, and $20 \mathrm{~mm}$ thick, respectively). Precipitation is faster in thick fractures because the fluid velocity is higher. Nevertheless, one may note that in this set of experiments precipitation is a weak effect, resulting in only a few mm thickness for the deposit of calcite. The precipitation step is limited to a few days, or even a few hours. Then dissolution happens and affects calcite, first the calcite previously deposited, then the carbonate rock itself. Figure 12 shows that for a thin fracture $(1 \mathrm{~mm}$ thick) the reactions are almost absent. For the other fractures the onset of carbonate dissolution occurs after 40 to $60 \mathrm{y}$.

\section{DISCUSSION}

The numerical approach presented here showed that the fluid that circulates through the fractured carbonates above the Aigion fault has the capacity to seal small fractures in a time range of a hundred to a few hundred years. The sealing of the fractures will have a drastic influence on the permeability of these carbonates. Indeed the matrix permeability of these carbonates is very low, in the range of $1 \mathrm{mD}$ (Sulem, personal communication): therefore any changes of the fracture permeabilities and fracture connection will influence the global permeability of the geological formations.

Such results are not easy to translate in terms of time required to seal the complete fracture network that is likely to be present in the hanging wall of the Aigion fault. The mineral precipitation is heterogeneous in space and results in heterogeneous sealing delays. The fracture network is probably made of fractures of different thicknesses and at present a quantitative description of the network at this scale is not available. The borehole images recorded in the well were interpreted in terms of density and directions (Daniel et al., 2004) but the fractures imaged by UBI (ultrasonic borehole imager) and FMI (formation micro imager) are thicker that the ones studied here. Therefore our models can only give a qualitative view of the fracture-network sealing.

In addition, the simulations showed that, for a given fracture and a given oversaturated fluid, the sealing time depends mainly on fluid velocity. A high velocity favours precipitation by supplying enough dissolved elements in time and space. In the northern shore of the Peloponnese (Fig. I) the fluid flow is driven by the topography, which could be translated in terms of pressure gradient at the fracture scale, but it is also driven by the seasonal rains that impose a variable water influx. Practically, in the simulations, the fluid velocity depends on the hypotheses (pressure gradient or flow) and on the fracture thickness. The speed of flow is higher in narrow fractures when the model is run with a constant flow-rate boundary condition. As a result, the precipitation rate increases through time. In contrast, when a pressure gradient is imposed, the speed of flow is higher in thick fractures and drops when, due to precipitation, the thickness of the fracture decreases. In this case a decrease of the precipitation rate through time is observed. 
We suggest that the boundary conditions that prevail on the natural hydraulic system in the studied fractures could be a mixture, or a succession in time, of the two types of situations modelled above; and we consider the calculated time of sealing as a rough estimate of the real rates that could result from the natural complexity.

A specific set of simulations showed that the fractures crossed by a fluid with the composition of seawater, at a slightly higher $p \mathrm{CO}_{2}$ value ( 0.01 instead of $0.007 \mathrm{bar}$ ), can be affected by dissolution, even if a transient precipitation step may take place initially. Therefore, in the Aigion area, one should consider that invasion by seawater may result in dissolution of the calcite present in the fractures.

\section{CONCLUSION}

Most of the results detailed above indicate delays of fracture sealing that, in the conditions that prevail in the hanging wall of the Aigion fault, range between 70 and $20000 \mathrm{y}$. These results concern fractures 1 to $20 \mathrm{~mm}$ thick. This means that the small scale fracture network can be sealed, in the natural condition of the Gulf of Corinth, in an interval of time corresponding to a century to a couple of centuries. The permeability variation can thus also be fast and recordable at this time scale and can impact on the hydraulic system during a seismic cycle.

An important issue debated in the community of earth physicists is to understand if the low friction coefficient inferred from the data on the major active fault is due to trapped overpressured fluids or to a dynamic effect (Bernard, 2001). The simple model presented in this paper, calibrated on data recorded between 600 and $1100 \mathrm{~m}$ burial depth, cannot answer the question. The earthquakes nucleate between 4 and $10 \mathrm{~km}$ in depth, around Aigion (Rigo et al., 1996). Nevertheless the model showed that the diagenetic process may, in the natural conditions of the hanging wall of the Aigion fault, change the permeability of rock over the time scale of a few tens to a few hundreds of years. It means that fractures opened by seismic events may be later sealed by the fluid circulation. In our model, the fractures permeability changes due to calcite deposit and therefore the global permeability, mainly due to the fracture networks, changes without any change of stress or strain or in any other boundary condition.

The simulations showed that the fluid sampled in the fault zone precipitates calcite, whereas seawater dissolves calcite. Data collected by INGV showed that, in the natural conditions of the footwall, the fluid mainly dissolves calcite (Pizzino, personal communication). Such differences of the potential rock-fluid interaction between the hanging and footwall of the Aigion fault are consistent with the hydraulic system encountered. As already mentioned, the global hydraulic conditions found in the AIG-10 well were the following:

- almost no fluid flow above the fault, or located in very specific and narrow aquifers;
- eruptive conditions below the fault (Cornet et al., 2004; Giurgea et al., 2004).

Karst is present in the footwall with a very high fluid flow rate, and the borehole images also emphasized the occurrence of karst (Daniel et al., 2004). It is not known yet if the karst is a new or an inherited feature, but the speed of the diagenetic processes is compatible with a recent karst due to the low permeability of the fault zone and to the huge gravity driven flow. The dating of calcite crystals, sampled from above and below the fault, will help to increase precision of the waterflow model.

\section{ACKNOWLEDGEMENTS}

This study has based on the data acquired through the projects 3F-Corinth (ENK6-CT-2000-00056) and DG-Lab (EVR1-CT-2000-40005), all funded by the European Community (VI PCRD). This study itself has been done thanks to the Groupement de Recherche: Corinth (INSUInstitut national des sciences de l'univers/IFP/IRNS Institut de recherche pour la suretée nucléaire). Additional information may be found on http://www.corinth-rift-lab.org

\section{REFERENCES}

Armijo, R., Meyer, B., King, A., Rigo A. and Papanastassiou, D. (1996) Quaternary Evolution of the Corinth Rift and its implications for the Late Cenozoic evolution of the Aegean. Geophys. J. Int., 126, 11-53.

Bernard, P., Briole, P., Meyer, B., Lyon-Caen, H., Gomez, GM., Tiberi, C., Berge, C., Cattin, R., Hatzfeld, D., Lachet, C., Deschamps, A., Courboulex, F., Larroque, C., Rigo, A., Massonet, D., Papadimitriou, P., Kassaras, J., Diagourtas, D., Macropoulos, K., Veis, G., Papazisi, E., Mitsakaki, C., Karakostas, V., Papadimitriou, E., Papanastassiou, D., Chouliaras, G. and Stravakakis, G. (1997) The Ms = 6.2, June 15, 1995 Aigion earthquake (Greece): evidence for low angle normal faulting in the Corinth rift. J. Seismol. 1, 131-150.

Bernard, P. (2001) From search of "precursors" to the research on crustal transients'. Tectonophysics, 338, 225-232.

Brosse, E., Margueron, T., Cassou, C., Sanjuan, B., Canham, A., Girard, J.P., Lacharpagne, J.C. and Sommer F., (2003) The formation and stability of kaolinite in Brent sandstone reservoirs: a modelling approach. Int Assoc. Sedimentol. Spec. Publ., 34, 383-408.

Cornet, F.H., Doan, M.L., Moretti, I. and Borm, G. (2004) Drilling through the active Aigion Fault : The AIG10 well observatory. Compte rendu Geoscience, 336, 4-5, 395-406.

Daniel, JM, Moretti, I., Micarelli, L., Essautier Chuyne, S. and Delle Piane C. (2004) Faulting in prefractured carbonates: macroscopic structural analysis of Ag10 Well (Gulf of Corinth, Greece). CRAS-Structural Geology/Deformation Mechanisms, 336, 4-5, 435-444.

Dromgoole and Walter (1990) Iron and manganese incorporation into calcite: Effects of precipitation rate, temperature, and solution. Chem.Geol., 81, 311-336.

Evans, JP. (1992) Greasing the fault. Nature, 358, 544-545.

Frima, C. (2003) Diagenèse et interaction eau/roche dans les carbonates de la faille d'Aigion, Grèce. Étude du temps de 
colmatage des fractures par de la calcite. Mémoire IGAL et DOC Public. Rapport IFP 57 575, 173.

Fritz, B. (1981) Étude thermodynamique et modélisation des réactions hydrothermales et diagénétiques. Sciences Géologiques, Mém. $n^{\circ}$ 65, université Louis-Pasteur de Strasbourg.

Giurgea, V., Rettenmaeier, D., Pizzino, L., Unkel, I., Hötzl, H. and Foster, A. (2004) Preliminary, hydrogeological interpretation of the Aigion area from Aig-10 borehole data. Compte rendu Geoscience, 336, 4-5, 467-476.

Hutcheon, I. and Abercrombie, H. (1990) Carbon dioxide in clastic rocks and silicate hydrolysis. Geology 18, 541-544.

Jaubert, M. (2003) Modélisation hydraulique de la région d'Aigion (Grèce) à l'aide du logiciel TEMIS 3D. Rapport IFP 57677.

Koukouvelas, I.K., Doutsos, T. (1996) Implication of structural segmentation during earthquakes: the 1995 Egion earthquake, Gulf of Corinth, Greece. Journal of Structural Geology, 18, 1381-1388.

Koukouvelas, I.K., Stamatopoulos, L., Katsonopoulou, D. and Pavlides, S. (2001) A paleoseismological and geoarchaeological investigation of the Eliki fault, Gulf of Corinth, Greece. Journal of Structural Geology, 23, 531-543.

Lebrón, I. and Suárez, D.L. (1998) Kinetics and mechanisms of precipitation of calcite as affected by $\mathrm{pCO}_{2}$ and organic ligands at $25^{\circ} \mathrm{C}$. Geoch. Cosmoch. Acta, 62, 3, 405-416.

Lee, Y.J., Morse, J.W. and Wiltschko, D.V. (1996) An experimentally verified model for calcite precipitation in veins. Chem. Geol., 130, 203-215.

Lee, Y.J. and Morse, J.W. (1999) Calcite precipitation in synthetic veins: implications for the time and fluid volume necessary for vein filling. Chem. Geol., 156, 151-170.

Le Pourhiet, L., Burov, E., Moretti, I. (2004) Rifting through a stack of inhomogeneous thrusts (study case in the Gulf of Corinth). Tectonics, 23, TC 4005.

Micarelli, L., Moretti, I. and Daniel, J.M. (2003) Influence of depth and amount of displacement of the characteristics of normal faults, case study in the Gulf of Corinth - Greece. Journal of Geodynamics, 36, 275-303.

Moretti, I., Delhomme, J.P., Cornet, F., Bernard, P., ScmidtHattenberger, C. and Borm, G. (2002) The Corinth Rift Laboratory: monitoring of actives faults. First Break, 20, 2.

Moretti, I., Sakellariou, D., Lykousis, V. and Micarelli, L. (2003) The Gulf of Corinth: an active half graben? Journal of Geodynamics, 36, 323-340.

Mucci, A. (1986) Growth kinetics and composition of magnesian calcite overgrowths precipitated from seawater: quantitative influence of orthophosphate ions. Geoch. Cosmoch. Acta, 50, 2255-2265.

Mucci, A. and Morse, J.W. (1983) The incorporation of Mg+2 and $\mathrm{Sr}+2$ into calcite overgrowths: influences of growth rate and solution composition. Geochim. Cosmochim. Acta, 47, 217-233.

Muir Wood and King, A. (1993) Hydrological signatures of earthquake strain. JGR, 98, 22035-22068.

Naville, C., Serbutoviez, S., Moretti, I., Daniel, J.M., Throo, A., Girard, F., Sotiriou, A., Tselentis, A., Skarpzelos, Ch., Brunet Ch. And Cornet, F. (2004) Pre-drill surface seismic in vicinity of AIG-10 well and post-drill VSP. Sismique de surface avant forage du puits AIG-10, et VSP après forage. CRAS-Structural Geology /Deformation mechanism, 336, 4-5, 407-415.
Nilsson, O. and Sternbeck, J. (1999) A mechanistic model for calcite crystal growth using surface speciation. Geoch. Cosmoch. Acta, 63, 2, 217-225.

Ori (1989) Geologic history of the extensional bassin of the Gulf of Corinth (?Miocene-Pleistocene), Greece. Geology, 28, 7, 651-654.

Pantosti, D., De Martini, P.M., Koukouvelas, I., Stamatopoulos, L., Pavlides, S., Palyvos, N. and Pucci, S. (2002) Paleoseismological trenching across the Eliki and Aigion faults (Gulf of Corinth, Greece). In: EGS XXVII General Assembly, Geophysical Research Abstracts, 4, Nice, France.

Parkhurst, D.L. and Appelo, C.A.J. (1999) User's guide to PHREEQC (version 2) A computer program for speciation, bathreaction, one-dimensional transport, and inverse geochemical calculation. US Geological Survey, Water-Ressources Investigation Report 99-4259.

Pizzino, L., Quattrocchi, F., Cinti, D. and Galli, G. (2004) Fluid geochemistry along the Eliki and Aigion seismogenic segments (Gulf of Corinth, Greece). Compte rendu Geoscience, 336, 4-5, 367-374.

Renard, F., Gratier, J.P. and Jamtveit, B. (2001) Kinetics of cracksealing, intergranular pressure solution, and compaction around active faults. Journal of Structural Geology, 22, 1395-1407.

Rettenmaier, D., Giurgea, V. and Foster, A. (2004) The AIG-10 drilling projet (Aigion, Greece): interpretation of the litho-log in the context of regional geology and tectonics. Compte rendu Geoscience, 336, 4-5, 415-424.

Rietbrock, A.C., Tiberi, C., Scherbaum, F. and Lyon-Caen, H. (1996) Seismic slip on a low angle normal fault in the Gulf of Corinth: evidence from high resolution cluster analysis of microearthquakes. Geophys. Res. Lett., 1, 1817-1820.

Rigo, A, Lyon-Caen, H., Armijo, R., Deschamps, A., Hatzfeld, D. Makioupoulos, K, Papadimitriou, P. and Kassaras I. (1996) A microseismic study of the western part of the Gulf of Corinth (Greece): implications for the large-scale normal faulting mechanisms. Geophys. J. Int., 126, 663-688.

Shiraki, R. and Brantley, S.L. (1995) Kinetics of near-equilibrium calcite precipitation at $100^{\circ} \mathrm{C}$ : an evaluation of elementary reaction-based and affinity-based rate laws. Geoch. Cosmoch. Acta, 59, 8, 1457-1471.

Sibson, R. (1992) Implications of fault-valve behaviour for rupture nucleation and reccurence. Tectonophysics, 211, 283-293.

Sibson, R. (1994) Crustal stress, faulting and fluid flow. In geofluids: origin, migration and evolution of fluids in sedimentary basins. Geological Society Special Publication, 78, 69-84.

Sorel, D. (2000) A Pleistocene and still-active detachment fault and the origin of the Corinth-Patras rift (Greece). Geology, 28, 1, 83-86.

Tenchine, S. (2001) Modélisation hydrogéologique du golfe de Corinthe (document public). Rapport IFP 56432.

Westaway, R. (2002) The Quaternary evolution of the Gulf of Corinth, central Greece: coupling between surface processes and flow in the lower crust. Tectonophysics, 6572.

Zhong, S. and Mucci, A. (1989) Calcite and aragonite precipitation from seaweter solutions of various salinities: precipitation rates and overgrowth compositions. Chem. Geol., 78, 283-299. 


\section{APPENDIX}

In the simulations two types of boundary conditions were tested. The modelled system is represented in Figure 3c. Its length along the $X$-axis is $L$ (here, $10 \mathrm{~cm}$ ). The fracture aperture is $b-h$, variable according to the thickness of neoformed calcite deposit $(h)$; its cross-sectional surface area is $a \cdot(b-h)$; in the example, $a=5 \mathrm{~cm}$. Accordingly, the fracture volume is $\mathrm{a} \cdot L \cdot(b-h)$. The whole system is characterized by a porosity $(\Phi)$ value and a permeability $(K)$ value. As the fracture has the highest contribution to these values, it can be assumed that:

$$
\Phi \approx \frac{a \cdot L \cdot(b-h)}{V}
$$

where $V$ is the rock-system volume; and that:

$$
u \approx K \cdot \delta P
$$

where $u$ is the water-flow velocity in the fracture and $\delta P$ is the pressure gradient.
The parameter $u$ is also given by:

$$
u=\frac{L}{t_{\text {res }}}
$$

where $t_{\text {res }}$ is the residence time of water in the fracture. $t_{\text {res }}$ is a function of flow rate $(f)$ :

$$
t_{\text {res }}=\frac{a \cdot L \cdot(b-h)}{f}
$$

From (A3) and (A4) it comes out that, at any time:

$$
u=\frac{f}{a \cdot(b-h)}
$$

a relation which is depicted in Figure 4a.

Comparing (A2) and (A5) gives the following equation:

$$
K \cdot \delta P=\frac{f}{a \cdot(b-h)}
$$

a relation that can be useful to understand the link between imposed pressure gradient and imposed flow rate as two distinct boundary conditions. 